\title{
A DESMILITARIZAÇÃO E A UNIFICAÇÃO DAS INSTITUIÇÕES MILITARES ESTADUAIS E A POLÍCIA CIVIL NO BRASIL: reflexos na segurança pública estadual.
}

\section{Demilitarization And The Unification Of State Military Institutions And The Civil Police In Brazil: Reflections On State Public Security}

Márcio Luís de Oliveira ${ }^{1}$

Edson Rodrigues de Oliveira ${ }^{2}$

\begin{abstract}
Resumo: A pesquisa em tela propõe uma visão jurídica constitucional e holística organizacional da prestação da segurança pública pelas Instituições Militares Estaduais e pela Polícia Civil, bem como os efeitos estimativos da Unificação na esfera estadual. A segurança pública é dever do Estado, direito e responsabilidade de todos, direito fundamental individual e coletivo, tão relevante, com sua capitulação própria, conforme a sintonia dos arts. 5, 6 e 144 da Constituição da República Federativa do Brasil - CRFB (BRASIL, 1988). O objeto da segurança pública está dividido na preservação da ordem, predominantemente afeto à Polícia Militar, e, na preservação da incolumidade das pessoas e do patrimônio, cabível ao Corpo de Bombeiros Militar, enquanto a Polícia Civil exerce a polícia judiciária em ambas as searas. Estas atribuições têm lastro estratégico na soberania nacional, com fulcro na eficiente fluência organizacional, paz social e bem comum de todos, sendo de responsabilidade da União, compartilhada aos Estados-membros (e não cabendo subdelegação aos Municípios). O modelo brasileiro de segurança pública tem origem no paradigma francês da "gendarmaria", com instituições militares e civis, atuando, respectivamente, como força física preventiva, repressiva e reativa do Estado, e na investigação criminal. As instituições militares têm características próprias, como uniformidade, solenidade, estrita impessoalidade, seleção rígida e devoção ao princípio de hierarquia e disciplina, e também força auxiliar do Exército brasileiro. Os excessos burocráticos, as deficiências gerenciais, os resultados trágicos das ações policiais e a comparação com a proposta do ciclo completo da polícia, bem como a racionalização econômica e administrativa, consolidam os argumentos da unificação paramilitar "anglo-saxã". Atualmente, essas múltiplas instituições são Secretarias de Estado-membro, mas não perderam o elo constitucional nacional.
\end{abstract}

Palavras-chave: Segurança Pública; Direito fundamental estratégico; Soberania nacional; Instituições Militares Estaduais e Polícia Civil; Desmilitarização e unificação.

Abstract: The research proposes a constitutional and holistic view of the organization of the provision of public security by the State Military Institutions and Civil Police, as well as the estimated effects of

\footnotetext{
${ }^{1}$ Mestre e Doutor em Direito Constitucional pela UFMG; Professor do Programa de Pós-graduação em Direito Ambiental e Desenvolvimento Sustentável da Escola Superior Dom Helder Câmara. Escola Superior Dom Helder Câmara - ESDHC, Minas Gerais - Brasil. E-mail: marcio.luis@uol.com.br

2 Graduado em Segurança Pública,Gestão Ambiental e Direito, Pós-gradualdo lato sensu em Teologia e Segurança Pública, Mestre em Direito Ambiental. Escola Superior Dom Helder Câmara - ESDHC, Minas Gerais - Brasil. Email: edsonrol@yahoo.com.br
} 
Unification at the state level. Public safety is the duty of the State, the right and responsibility of all, fundamental individual and collective right, so relevant, with its own capitulation, according to the harmony of the arts. 5, 6 and 144 of the Constitution of the Federative Republic of Brazil - CRFB (BRAZIL, 1988). The object of public security is divided into the preservation of order, which is predominantly linked to the Military Police, and, in the preservation of the integrity of the people and the patrimony, applicable to the Military Fire Brigade, while the Civil Police exercises judicial police in both the scopes. These responsibilities have a strategic weight in national sovereignty, focusing on efficient organizational fluency, social peace and the common good of all, being the responsibility of the Union, shared with the Member States (not subdelegating the Municipalities). The Brazilian model of public security, in the member states, originates in the French paradigm of the "gendarmerie", with military and civil institutions, acting respectively as a preventive, repressive and reactive physical force of the State, and in criminal investigation. Military institutions have their own characteristics, such as uniformity, solemnity, strict impersonality, rigid selection and devotion to the principle of hierarchy and discipline, and also an auxiliary force of the Brazilian Army. Bureaucratic excesses, managerial deficiencies, tragic results of police actions and comparison with the proposal of the complete police cycle, as well as economic and administrative rationalization consolidate the arguments of the "AngloSaxon" paramilitary unification. Currently, these multiple institutions are Secretaries of State, but they have not lost the national constitutional link.

Keywords: Public Safety; Fundamental Right; Sovereignty; Autonomy; State Military Institutions.

\section{INTRODUÇÃO}

\section{A Temática "A desmilitarização e unificação das Instituições Militares Estaduais e a} Polícia Civil no Brasil: reflexos na segurança pública estadual.", à égide, ad exemplus do trâmite da Proposta de Emenda Constitucional n. 51 - PEC 51 (BRASIL, 2013), propõe reflexão diagnóstica e jurídica no tocante à origem do modelo vigente e concorrente, expectativas à almejada eficiência na prestação da segurança pública estadual e a proposições existentes de desmilitarização e unificação.

Para a consecução dos resultados almejados, pela concernente pesquisa, emprega-se a metodologia jurídico-teórica com raciocínio dedutivo. Outrossim, lobriga-se como objetivo geral, pelo crivo conceitual de soberania nacional e autonomia estadual, o balizamento à maximização eficiência da prestação da segurança pública estadual.

$\mathrm{Na}$ órbita dos objetivos específicos, examinam-se os motivos da alocação das atribuições de interesse nacional aos Estados-membros, bem como as características das IME's e da Polícia Civil, suas atribuições constitucionais, óbices característicos à fluência do ciclo completo de polícia e reflexões comparativas e ensaios de fatos concretos ao modelo paramilitar estadunidense.

Noutra senda, relevantes os holofotes conceituais de "ética e moral" habermasiano. Às lentes do princípio da impessoalidade e do devido tratamento isonômico a todos, aos óculos dos arts. 
5o e 37 da CRFB (BRASIL, 1988), urge, também a sinergia da legitimidade (HABERMAS ${ }^{3}, 2003 ; 1991$ ) dos atos pela lupa da ética e da moral. Segundo Habermas (1990, p. 98), a legitimidade é proporcional à circunscrição que ocupa democraticamente a vontade da maioria e o assentimento da minoria. Também, agregando Habermas (1992, p. 294, 299), explicitou que, tanto "ética", quanto "moral", etimologicamente, têm acepção de "casas ou moradas" com suas respectivas regras internas de sustentabilidade e integridade. Nesta assertiva asseverou Figueiredo (2008), fazendo a distinção grega do termo "ética", congregando dois sentidos, o primeiro decorrente da grafia $\eta \theta_{\circ} \zeta$ - êthos, significando morada, caráter ou índole, e, o segundo, $\varepsilon \boxminus o \zeta$ - éthos, traduzido-se por hábitos ou costumes, enquanto o termo morada, deriva do latim moralia, designando o mesmo sentido de "éthos". Assim, o conceito de "ética" assume, por sua vez, o caráter privado, mesmo que em habitação coletiva (verbi gratia: igreja, raça, partido político, área de formação do conhecimento, dentre outros), em que um mesmo indivíduo pode congregar vários "êthos", enquanto o termo "moral" é amplo e transcende os interesses privados, pois visam o bem comum de todos, sem quaisquer discriminações sociais, portanto, prevalecendo-se sobre os interesses éticos.

Nesse diapasão contextual, eleva-se o princípio da "moralidade administrativa", no caput do art. 37 e no inciso LXXIII do art. 50 da CRFB (BRASIL, 1988), que, conforme doutrinado por Di Pietro (2014, p. 78), contempla os elementos de "honestidade e justiça", ou seja, no enaltecimento o bem comum de todos, à impessoal e eficiente prestação estatal, sem quaisquer discriminações, referendando a supremacia do interesse público, peculiar à "Casa Moral”, ipsis:

[...] distinguir não só o bem e o mal, o legal e o ilegal, o justo e o injusto, o conveniente e o inconveniente, mas também entre o honesto e o desonesto; há uma moral institucional, contida na lei, imposta pelo Poder Legislativo, e há a moral administrativa, que "é imposta de dentro e vigora no próprio ambiente institucional e condiciona a utilização de qualquer poder jurídico, mesmo o discricionário".

Outra contribuição à temática, por Habermas (1992, p.296), segundo ainda à leitura de Herrero (1986, p.29), corresponde ao conceito de "mundo da vida", que, conforme interpreta ainda Oliveira (2013, p. 31), representa o ambiente e fatores de convivência de determinada pessoa ou grupo, inferindo na respectiva bagagem cultural, intelectual e de experiência. Destarte, Oliveira (2013,

\footnotetext{
${ }^{3}$ Argumentos em prol da legitimidade do direito devem ser compatíveis com os princípios morais da justiça e da solidariedade universal - sob pena de dissonâncias cognitivas - bem como com os princípios éticos de uma conduta de vida auto-responsável, projetada conscientemente, tanto de indivíduos, como de coletividades. (Habermas, 2003, p. 133).
} 
p. 31) associa o substrato do "mundo da vida" ao "acervo cultural axiológico". Ademais, Maingueneau $(2000, \text { p. } 3)^{4}$ conceitua semanticamente o termo "lugar", que, de acordo com o cenário do mundo da vida ou acervo cultural axiológico peculiar, poderá modificar a interpretação do objeto perscrutado, ou seja, não será percebido da mesma forma por atores em posições diferentes no ambiente. Assim, a falta de nivelamento de conhecimento prejudica a racionalidade comunicativa e, por conseguinte, o democrático discurso dialético (HABERMAS, 2003, p. 142 e 146):

E "discurso racional" é toda a tentativa de entendimento sobre pretensões de validades programáticas, na medida em que ele se realiza sob condições da comunicação que permitem o movimento livre de temas e contribuições, informações e argumentos no interior de um espaço público constituído através de obrigações ilocucionárias.

$[\ldots]$.

Para a auto-organização cumpre-se criar o sistema de direito e a linguagem mecanismo de que permite a comunidade entender-se enquanto associação voluntária de membros do direito iguais e livres.

No tocante às Instituições Militares Estaduais - IME's, pelo crivo ético, interna corporis, existem os círculos dos oficiais e das praças, enquanto na Polícia Civil, em sentido amplo, delegados e detetives, entretanto a prestação constitucional e regência administrativa admite apenas o manto moral, ou seja, visando a uniformidade do bem comum de todos sem quaisquer discriminações.

\section{A SOBERANIA DA SEGURANÇA PÚBLICA E A AUTONOMIA DOS ESTADOS}

O federalismo brasileiro, segundo Moraes (2013, p.116), Barros (2013, p. 60 - 67), Silva (2013, p. 107) tem fulcro na autonomia simétrica, centrífuga e cooperativa no âmbito da União, Estados-membros, Municípios e do Distrito Federal, mas sobretudo, a soberania é consorciada apenas à União, na representação do interesse nacional. Neste concerto, a segurança pública é de interesse comum de todos, independente de localidade específica na circunscrição nacional, portanto, a matéria está alicerçada na "soberania" e a gestão administrativa na "autonomia", nos termos do art. 18 da CRFB (BRASIL, 1988). Neste contexto pronunciou Ramos (2013, p. 85):

O Estado Federal brasileiro é composto de Estados que gozam de "autonomia". Significa autogoverno - governo próprio mediante regras próprias. Essa

\footnotetext{
${ }^{4}$ MAINGUENEAU, Domenique. Termos-chave da análise do discurso. Tradução de Márcio Venício Barbosa. Belo Horizonte: UFMG. 2000.
} 
autonomia é a capacidade de auto-organização através de uma Constituição que o seu Poder Constituinte estabelece. [...].

(...)

Os estados constituem-se em instituições típicas do Estado Federal. São as grandes entidades-componentes que dão a estrutura conceitual dessa forma de Estado. Sem os mesmos, não poderá haver federação, independentemente dos nomes que receberam: Estados, no Brasil, Estados Unidos e Venezuela; [...]. O que caracteriza não é o nome, mas a autonomia.

A soberania não compete aos entes federativos isoladamente, mas à reunião de todos em um maior, concentrado na União, como expressão federativa ou nacional. Nesta senda, argumentaram também Moraes (2014, p. 289), Costa e Oliveira (2015, p. 218, 219), Pimenta (2007, p. 20, 24, 28), Castilho $(2013$, p. 6, 8) Oliveira $(2013$, p. 79,130$)$, que a União goza da soberania, assim como também de autonomia, como os demais entes federativos, nos limites constitucionais, conforme Silva (2013, p. 497):

\begin{abstract}
A União é a entidade federal formada pela reunião das partes componentes, constituindo pessoa jurídica de Direito Público interno, autônoma em relação às unidades federadas (ela é unidade federativa, mas não é unidade federada) e a que cabe exercer as prerrogativas da soberania do Estado brasileiro. Estado federal, com o nome de República Federativa do Brasil, é o todo, ou seja, o complexo constituído da União, Estados, Distrito Federal e Municípios, dotado de personalidade jurídica de Direito Público internacional (grifos do autor).
\end{abstract}

Dogmaticamente, aludindo-se a dispositivos constitucionais de fundamentação da soberania do Estado-nação e matérias estratégicas privilegiadas são pluralizados na CRFB (BRASIL, 1988), vasta gama de autores reafirmam os fundamentos do Estado brasileiro ao corolário lógico da soberania, a exemplo de Costa e Oliveira (2015, p. 219), Oliveira (2013, p. 130) e Silva (2013, p. 106), que sintetizou: "O Estado brasileiro, segundo o art. 10, tem como fundamentos a soberania, a cidadania, a dignidade da pessoa humana, os valores sociais do trabalho e da livre iniciativa e o pluralismo político.". E sacramentando a questão, Silva (2013, p. 182), referendou: "São direitos constitucionais na medida em que se inserem no texto de uma constituição ou mesmo constem de simples declaração solenemente estabelecida pelo poder constituinte. São direitos que nascem e se fundamentam, portanto, no princípio da soberania popular.". Na mesma conexão e vinculação à demanda de segurança pública, Silva (2013, p. 107), propõe, com base no art. 30 da CRFB (BRASIL, 1988), como objetivos fundamentais do Estado brasileiro a construção de uma sociedade: “[...] livre, justa e solidária; garantir o desenvolvimento nacional; erradicar a pobreza e a marginalização, deduzir as desigualdades sociais e regionais; e promover o bem de todos, sem preconceitos de origem, raça, sexo: cor, idade e de outras formas de discriminação [...].". 
Por analogia e compreensão temática, a soberania também pode ser aflorada nos aspectos etio, mens e teleo legis da norma. No tocante à regência circunscricional normativa, à égide do processo legislativo, nos termos do art. 59 e limites do §4으, do art. 60, da CRFB (BRASIL, 1988), Barros (2013, p. 62, 63) categoriza o alcance teleológico, classificando as normas em: 1) "federal", quer se limita à circunscrição de referência do respectivo ente federativo, a exemplo da Lei n. 9.784 (BRASIL, 1999), aplicável aos servidores públicos federais, a Lei n. 14.184 (MINAS GERAIS, 2002); 2) "federativa" com repercussão transitiva a outros entes, com aplicação procedimental ao princípio da legalidade estrita dos servidores públicos - fazer ou deixar de fazer somente o que for expresso por lei (DI PIETRO, 2014, p. 384), a exemplo das disposições predominantes da Lei Complementar n. 140 (BRASIL, 2011a) e da Lei n. 8.666 (BRASIL, 1993); e, 3) "nacional", expressando ordenação a todos, em condições de igualdade, em todos os rincões da federação, a exemplo da Lei n. 9.605 (BRASIL, 1998), do Decreto-Lei n. 2.848 (BRASIL, 1940). Destarte, descrevendo as propriedades técnicas e jurídicas da soberania, propalou Pimenta (2007, p. 20): “Soberania, é o poder dos poderes. É ela que explica toda a ordem jurídica nacional e internacional. É o poder maior que emana do povo, e que em seu nome deve ser exercido. A soberania é o elo que une duas realidades, o Estado e o Direito.".

Outrossim, o termo "república", em consonância à pujança da soberania, consoante Pimenta (2007, p. 28), vem do latim “[...] res (coisa) e pública (de todos, pública), consistindo, em um conceito clássico, no governo 'de todos', com o objetivo de alcançar o bem comum da sociedade". E, complementando, destaca: "Na República, os governados podem também ser governantes, ou pelo menos abre-se a possibilidade de que o povo participe do exercício do poder. A República tem como características básicas a temporariedade e eletividade". Consagrando a proposição, em sentido análogo, Castilho $(2013$, p. 6, 8) sintetiza a concepção própria e internacional de soberania, explanando a gênese francesa do interesse e representação popular:

Em síntese, a Soberania restou moldada como poder absoluto, sagrado, inviolável e ilimitado do soberano, poder este que, conferido pelo pacto social e dirigido pela vontade geral, era exercido sobre todos. [...]. Essas teorias democráticas registraram evolução quanto a essa específica identificação de titularidade. De início, o titular era o próprio povo, como ente fora do Estado. Posteriormente, em razão da Revolução Francesa, a Soberania foi conferida à Nação. Que é o próprio povo, mas expresso por uma ordem constituída. Finalmente, o Estado passa a ser o detentor da Soberania (grifos do autor).

Destarte, apesar da situação de pretensa delegação parcial da execução e controle administrativo da segurança pública aos Estados-Membros e ao Distrito Federal, em face do arcabouço estratégico do "Título V", da CRFB (BRASIL, 1988), pelo crivo da soberania nacional (circunscrição mais 
ampla), conforme explana Di Pietro (2014, p. 481) e Rocha (1997, p. 242), as atribuições afetas ao art. 144 da CFFB (BRASIL, 1988) não podem ser subdelegadas. Nesse sentido da restrição de competências apenas aos referidos entes, descreveu Casseb (2013, p. 360):

Visualizam-se, então, competências constitucionalmente atribuídas a apenas determinados Entes, de modo horizontal, algumas delas delegáveis (art. 22, CF) e outras não (arts. $21 ; 25, \S \S 1$, 2 으 e 3 ㅇ e 30, I, CF, entre outros exemplos), como também competências comuns a União, Estados, Distrito Federal e municípios (art. 23, CF), além das denominadas competências concorrentes (art. 24, CF) e suplementar (arts. 24, §§ 2으, 3으 e 4ㅇe e 30, II, CF).

Conforme Oliveira, 2017, p. 29), com escopo nos postulados de Dimoulis e Martins (2009, p. 56,57$)$, Bonavides (2010, p. 569, 570), Canotilho (2010, p. 408) e Andrade (2014, p. 32), a segurança pública é um direito fundamental de prerrogativa indisponível, transcendendo às primeira (liberdade) e segunda (igualdade) gerações, por estar alicerçada no caráter transindividual de titularidade difusa, independentemente de identificação da pessoa, mas no manto da fraternidade ou solidariedade, alcançando não só brasileiros, mas também estrangeiros na circunscrição do País, portanto, em patamar de terceira geração (VASAK , 1983, 1997). Nessa égide portaram os julgados do Supremo Tribunal Federal (STF) BRASIL, 2016):

O direito a segurança é prerrogativa constitucional indisponível, garantido mediante a implementação de políticas públicas, impondo ao Estado a obrigação de criar condições objetivas que possibilitem o efetivo acesso a tal serviço. É possível ao Poder Judiciário determinar a implementação pelo Estado, quando inadimplente, de políticas públicas constitucionalmente previstas, sem que haja ingerência em questão que envolve o poder discricionário do Poder Executivo. (BRASIL, 2011h) ${ }^{5}$

Noutra senda, consoante Oliveira (2017, p. 29) outra característica interessante é que a segurança pública não gera direito adquirido, sendo um bem jurídico indisponível. Como exemplo, uma lei de segurança contra incêndio e pânico pode revogar a lei anterior e exigir a modernização do sistema predial, independente do já instalado e aprovado com fulcro na lei anterior, cabendo apenas flexibilidade nas regras de transição, pois a regra é a maximização de mecanismos de segurança. Em outro extremo, determinado comerciante não pode ser atendido no pedido da retirada de um policiamento ostensivo das extremidades de sua atividade econômica, sob a alegação de redução de clientes. Assim conclui o autor:

\footnotetext{
${ }^{5}$ No mesmo sentido, BRASIL, $2013 f$.
} 
Depreende-se, então, que, sob o manto constitucional, a segurança pública é um bem jurídico difuso indisponível, insculpido na soberania estratégica nacional, dever do Estado, direito fundamental democrático, solidário, portanto, de terceira geração e de responsabilidade de todos, não gerando direito adquirido. A segurança pública está estabelecida nos pilares da preservação da ordem pública e na preservação da incolumidade das pessoas e do patrimônio, prestados taxativamente, segundo o legado da Carta Magna, por órgãos específicos da administração direta, representantes da força física, investigativa ou coercitiva estatal, detentores de poder-dever de polícia, cada qual com seu consórcio de atribuições afins, não cabendo a subdelegação aos municípios.

A proposição da soberania como sustentabilidade da segurança pública implica ainda outras incursões, que serão examinadas por amostragem adiante, como a competência para procedimentos afetos em circunscrições de outros Estados-membros vizinhos ou mesmo da União, a exemplo de delitos comuns em universidades federais e ou repartições análogas. Apesar da delegação constitucional aos Estados -Membros, às IME's e a Polícia Civil estão sob o manto da soberania nacional, portanto, sob a gestão simultânea e ascendente do Ministério da Justiça.

\section{A DEMANDA DA SEGURANÇA PÚBLICA}

A ratione de ser e existir, ou aspectos onto-epistemológicos, da segurança pública decorre da própria necessidade organização, estrutura de subsistência do Estado-nação e conforto ao convício humano na sociedade. Na República Federativa do Brasil a segurança pública está estabelecida no supedâneo da soberania nacional e, por conseguinte, no caso das IME's e da Polícia Civil, mesmo que o art. 144 da CRFB (BRASIL, 1988) tenha promovida a delegação parcial aos Estados-membros, a matéria não se trata de interesse local, mas nacional. Nesta senda, a aquilatada e homogênea missão fundamental e estratégica ${ }^{6}$ da prestação da segurança pública não pode ser subdelegada dos Estados aos Municípios.

Em síntese, conforme elucida Oliveira (2013, p.9-17), escudado, em especial, nos postulados de Heidegger, Sartre, Frei Betto, Hegel, a base da sociedade é o ser humano, que congrega subjetividade e o livre arbítrio. A sociedade, por sua vez é o alicerce da organização do Estado e da regulação do Direito, na tríade da liberdade, igualdade e solidariedade, como marco do

\footnotetext{
${ }^{6}$ Estratégia é uma palavra com origem no termo grego strategia, que significa plano, método, manobras ou estratagemas usados para alcançar um objetivo ou resultado específico. (SIGNIFICADOS, 2017).
} 
desenvolvimento social, proporcionais à resultante da harmonia estabelecida. Neste sentido, preconizou Oliveira (2013, p. 17):

[...] o ser humano existe como um ser processo de atualização (pluridimencional e transexistencial, e, por isso, sempre, plenipotencialmente inacabado), mas também finito (histórico). Nesse sentido o ser humano está em constante movimento de autorealização; contudo, nunca se realiza em plenitude (por inteiro), mas apenas na plenipotencialidade possível (a dos momentos de existência). E essa impermanência do existir - imanente à condição humana desvela-se num ser essencialmente conflituoso.

Outrossim, Silva (2013a) destaca a constante busca da felicidade pelo homem, em consonância a finalidade estatal do bem comum. Para tanto, a racionalidade e virtudes essenciais devem prevalecer, para o equilíbrio entre o déspota e o emotivo, especialmente em inibição aos sentimentos de "ira", à simbiose da ataraxia7. Em sentido análogo, destaca também Megale (2008), com fundamento em Aristóteles (1998) e Platão (1993, 1999), sob o elo de entendimento, ainda, de Aquino (2004), Aquino (2005), Agostinho (1955), Kant (1988) e Kant (2003), a importância das virtudes da temperança, sabedoria, fortaleza, prudência e justiça, como lemes do comportamento humano. Desta feita, os desvios, tanto dos representantes do Estados, quanto dos cidadãos devem ser penalizados.

O cotejo entre as particularidades sui generis do homem, seu mundo da vida, acervo cultural axiológico, individual e coletivo, a falibilidade e desvios comportamentais, as paixões, egocentrismos, as vaidades e inferências da pessoalidade, verbi gratia, ao suportável convívio social, desde os primórdios, passou a exigir convenções e regras, sejam consuetudinárias e principiológicas, predominantes na regência anglo-saxônica, ou mesmo dogmática, típica do paradigma weberiano ou europeu (GODOI, 2008; PETRY, 2004; WEBER, 2004; OLIVEIRA, 2013; OLIVEIRA, 2017). Nesta assertiva, o Brasil, constitucional e administrativamente, adotou a tecnocrácia de Weber (2004, p. 198), em sentido da positivação e categorização de princípios e regência estrutural do Estado, instituídos à baliza da legalidade e elementos de validade do ato administrativo, além da competência funcional dos órgãos e de seus servidores:

I. Rege o princípio das competências oficiais fixas, ordenadas, de forma geral, mediante regras: leis ou regulamentos administrativos, isto é: 1) existe uma distribuição fixa das atividades regularmente necessárias para realizar os fins do complexo burocraticamente dominado, como deveres oficiais; 2) os poderes de mando, necessários para cumprir estes deveres, estão também fixamente distribuídos, e os meios coativos (físicos, sacros ou outros) que eventualmente

\footnotetext{
${ }^{7} \mathrm{O}$ termo grego ataraxía , introduzido por Demócrito (c. 460-370 a.C.), significa tranquilidade da alma, ausência de perturbação. É um conceito fundamental da filosofia epicurista e dos céticos, e pode traduzir-se como imperturbabilidade, ausência de inquietação ou serenidade do espírito. Ataraxia é a disposição do espírito que busca o equilíbrio emocional mediante a diminuição da intensidade das paixões e dos desejos e o fortalecimento das alma face às adversidades. (ATARAXIA, 2003)
} 
podem empregar estão também fixamente delimitados por regras; 3) para o cumprimento regular e contínuo dos deveres assim distribuídos e o exercício dos direitos correspondentes criam-se providências planejadas, contratando pessoas com qualificação regulamentada de forma geral.

O paradigma europeu, propondo regência comportamental escrita, prevalece na CRFB (BRASIL, 1988), refletindo no "princípio da legalidade", na combinação dos art. 5o, inciso "II - ninguém será obrigado a fazer ou deixar de fazer alguma coisa senão em virtude de lei;"; inciso "XXXIX - não há crime sem lei anterior que o defina, nem pena sem prévia cominação legal;", e, o caput do art. "37 - A administração pública [...] obedecerá aos princípios de legalidade, impessoalidade, moralidade, publicidade e eficiência e, [...].". O paradoxo orienta que, enquanto o servidor público só pode fazer o que estiver previsto em lei, o cidadão pode fazer tudo aquilo que não for proibido por lei (MOTA e SPITZCOVSKY, 2001, p. 211, 212; DI PIETRO, 2014, p. 384).

Segurança pública, etimologicamente, conforme Cunha (1986. p.711), refere-se a um termo composto, que vêm do latim "securitas" - aquilo que está fora de perigo, aglutinado a partícula "publicum" - aquilo que pertence ou é destinado ao povo. Nesta senda, implica, objetivamente, ausência de perigo, e, subjetivamente, na confortável sensação decorrente da realidade concreta. Neste diapasão preconizou Cretella Júnior $(1992$, p.185) que a segurança pública visa proteger e garantir os direitos e deveres fundamentais individuais e coletivos, ou seja: "Garantir a segurança é, de fato, garantir o exercício das demais liberdades, porque a vis inquietativa impede o homem de agir.". Nessa égide, Silva (2001), conceituou segurança pública como a manutenção da ordem pública interna, para pacífica convivência social, isenta de ameaça de violência em sentido amplo ou ilícitos penais.

Historicamente, as constituições federais anteriores não explicitaram as atribuições, definições e órgãos afetos, como formalizado na redação da CRFB (BRASIL, 1988), mas propuseram regulação das atividades programaticamente por leis, fazendo menções superficiais por meio dos termos "segurança pública, segurança e segurança individual". A Constituição inaugural (BRASIL, 1824) fez estas alusões nos arts. 34, 148 e 179. Já a segunda Constituição (BRASIL, 1891), aludiu à competência legislativa do Congresso Nacional na regulação da atividade de "polícia", nos termos do art. 34, inciso 30, e, o direito fundamental a segurança individual, no seu art. 72. A terceira Carta (BRASIL, 1934), reiterou a segurança individual como direito fundamental, no seu art. 113, e, no art. 5ำ, incisos V, XI e XIX, alínea I, preconizou a competência privativa da União para:

V - organizar a defesa externa, a polícia e segurança das fronteiras e as forças armadas;

[...]. 
XI - prover aos serviços da polícia marítima e portuária, sem prejuízo dos serviços policiais dos Estados;

$[\ldots]$.

XIX - legislar sobre:

I) organização, instrução, justiça e garantias das forças policiais dos Estados e condições gerais da sua utilização em caso de mobilização ou de guerra;

[...].

Art 113 - A Constituição assegura a brasileiros e a estrangeiros residentes no País a inviolabilidade dos direitos concernentes à liberdade, à subsistência, à segurança individual e à propriedade, nos termos seguintes:

A tetra Constituição (BRASIL, 1937) manteve a mesma competência privativa organizacional e legislativa atribuída à União, no art. 15, inciso IV, e inserindo novos termos, como expressou o art. 16, inciso "Il - a defesa externa, compreendidas a polícia e a segurança das fronteiras;", inciso V (o bem-estar, a ordem, a tranqüilidade e a segurança públicas) e inciso "XXVI - organização, instrução, justiça e garantia das forças policiais dos Estados e sua utilização como reserva do Exército;[...].". Mantendo uniformidade nestas proposições, em sentido da regulação programática por lei, perseveraram ainda as constituições sucessivas (BRASIL, 1946; BRASIL, 1967).

A redação da Constituição antecedente (BRASIL. 1967), mantida perante a Emenda Constitucional n. 1 (BRASIL, 1969), no seu art. 13, §4으, emprega termos similares aos autores, sugerindo a perpetuação da ligação das atividades de manutenção da ordem pública à "vis inquietativa" e não as atividades de preservação da incolumidade pública (ou busca e salvamento):

Art. 13. Os Estados organizar-se-ão e reger-se-ão pelas Constituições e leis que adotarem, respeitados dentre outros princípios estabelecidos nessa Constituição, os seguintes:

$[\ldots]$;

$\S 4$ 을 As polícias militares, instituídas para a manutenção da ordem pública nos Estados, nos Territórios e no Distrito Federal, e os corpos de bombeiros militares são considerados fôrças auxiliares, reserva do Exército, não podendo seus postos ou graduações ter remuneração superior à fixada para os postos e graduações correspondentes no Exército (grifo nosso).

Predominantemente, a temática da preservação da incolumidade pública das pessoas e do patrimônio, segundo pilar da segurança pública, sugerindo vício pelo postulado da constituição anterior (BRASIL, 1967), tratando segurança pública apenas como preservação da ordem, passa despercebida pelos autores, diante da modernidade da CRFB (BRASIL, 1988), omitindo-se a competência atribuída aos Corpos de Bombeiros Militara exemplo de Lazzarini (1991, p. 27, 28) e Baracho (1987, p. 73). 
A CRFB (BRASIL, 1988) inovou em relação a Constituição revogada (BRASIL, 1967), que no seu §4, do art. 13, tratava como objeto vigente a "preservação da ordem". 0 art. 144 (BRASIL, 1988) preconizou a competência e a exclusividade dos órgãos especificados, definindo ainda à prestação da Segurança pública, ratificando o interesse estratégico nacional (fundamentado nas razões de soberania). Dessarte, o Estado-nação necessita de proteção e estabilidade federativa perante os demais países, bem como, simultaneamente, da garantia interna do exercício dos direitos fundamentais. A Carta Magna (BRASIL, 1988) confirma a necessidade de segurança a todas as pessoas e do patrimônio, na circunscrição territorial do País, como referendam o caput dos arts. 50 e 6으, reverberados ainda nos artigos 136 e caput do art. 144, todos da):

Art. 50 Todos são iguais perante a lei, sem distinção de qualquer natureza, garantindo-se aos brasileiros e aos estrangeiros residentes no País a inviolabilidade do direito à vida, à liberdade, à igualdade, à segurança e à propriedade, nos termos seguintes:

(...)

Art. 60 São direitos sociais a educação, a saúde, a alimentação, o trabalho, a moradia, o lazer, a segurança, a previdência social, a proteção à maternidade e à infância, a assistência aos desamparados, na forma desta Constituição.

(...)

Art. 136. O Presidente da República pode, ouvidos o Conselho da República e o Conselho de Defesa Nacional, decretar estado de defesa para preservar ou prontamente restabelecer, em locais restritos e determinados, a ordem pública ou a paz social ameaçadas por grave e iminente instabilidade institucional ou atingidas por calamidades de grandes proporções na natureza.

(...)

Art. 144. A segurança pública, dever do Estado, direito e responsabilidade de todos, é exercida para a preservação da ordem pública e da incolumidade das pessoas e do patrimônio, através dos seguintes órgãos:

O art. 144 da CRFB (BRASIL, 1988), por meio dos incisos I ao V, taxativamente, elencam os órgãos "exclusivos", incumbidos da alusiva prestação, quais sejam: no âmbito da União, as Polícias Federal, Rodoviária e Ferroviária Federais, e, na esfera dos Estados-membros, a Polícia Civil, Polícia Militar e Corpos de Bombeiros Militares.

A matéria de segurança pública, à redação do caput do art. 144, da CRFB (BRASIL, 1988), divide-se em dois baluartes, o primeiro corresponde à preservação da ordem pública, enquanto o segundo equivale à preservação da incolumidade pública das pessoas e do patrimônio. No exame temático, às Polícias e Corpos de Bombeiros militares estaduais, sob o imperativo do §5, cumprem: “§ 5 Às polícias militares cabem a polícia ostensiva e a preservação da ordem pública; aos corpos de bombeiros militares, além das atribuições definidas em lei, incumbe a execução de atividades de defesa civil". As atividades de trânsito foram categorizadas e definidas como matérias típicas da 
segurança pública, por força expressa do art. 144, §§ 8 o e 10, com incumbência, na circunscrição do Estado, à Polícia Militar, e, nas rodovias e estradas federais, à Polícia Rodoviária Federal (ou Polícia Militar mediante convênio). Nesse concerto esclareceu Oliveira (2017, p, 77):

\begin{abstract}
Assim, questionável se faz, por exemplo, na matéria de trânsito, que é explicitamente de segurança pública (inciso II, §10, art. 144, CRFB, BRASIL, 1988), à validade das multas de trânsito de radares emitidas por órgãos administrativos municipais, estaduais e federais, não previstos no rol de titularidade, que não, nos termos da lei, ratificadas pela autoridade coercitiva competente. Diante desta exemplificativa celeuma o STJ (BRASIL, 2016), discutindo a matéria manteve suspensa a questão, pois, a partir do momento que a decidir com fulcro na leitura hermenêutica ampliativa ao Código de Trânsito Brasileiro, Lei n. 9.503 (BRASIL, 1997), como discorreu o Ministro Benjamin, sem observar a posição do Supremo e leitura filológica do art. 144 da CRFB (BRASIL, 1988), contemplando o DNIT e outros como competente, subsume-se, estarão criando outros órgãos de segurança, cabendo a pacificação no Supremo Tribunal Federal e referências aos mencionados julgados.
\end{abstract}

Em relação à estratégia de definição de órgãos públicos específicos, com efetivos devidamente treinados, a própria CRFB (BRASIL, 1988) esclareceu o limite das atribuições das guardas municipais e a segurança patrimonial desta Administração. Atualmente, muitos conflitos de competência poderiam ser dirimidos com a breve leitura dos $\S \S 8$ e 10 do art, 144, da CRFB (BRASIL, 1988). Assim, a constituição não recepcionou nenhum outro órgão substituto ou subsidiários aos previstos. Uma ilustração clássica é a questão de órgãos executivos de trânsito de infraestrutura viária (DNIT e DEER), aplicando multas de trânsito, quando os órgãos competentes são a Polícia Rodoviária Federal e as Polícias Militares. Há um grande equívoco na interpretação do Código de Transito Brasileiro e dissonância à Carta Magna, pois, o exercício do poder de polícia (DI PIETRO, 2014, p. 123), administrativo ou na repressão criminal, cabem à força física do Estado (respectivos órgãos de segurança pública). Os aludidos dispositivos asseveram:

$\S 80$ Os Municípios poderão constituir guardas municipais destinadas à proteção de seus bens, serviços e instalações, conforme dispuser a lei. $[\ldots]$.

$\S 10$. A segurança viária, exercida para a preservação da ordem pública e da incolumidade das pessoas e do seu patrimônio nas vias públicas:

I - compreende a educação, engenharia e fiscalização de trânsito, além de outras atividades previstas em lei, que assegurem ao cidadão o direito à mobilidade urbana eficiente; $\mathrm{e}$ II - compete, no âmbito dos Estados, do Distrito Federal e dos Municípios, aos respectivos órgãos ou entidades executivos e seus agentes de trânsito, estruturados em Carreira, na forma da lei. 
Em sentido análogo, destacou Oliveira (2017, p. 62) o reconhecimento e sinergia da proteção à fauna, flora e todo o patrimônio público ambiental como objeto da segurança pública, por conexão ao art. 225, da CRFB (BRASIL, 1988), que preconiza: "Todos têm direito ao meio ambiente ecologicamente equilibrado, bem de uso comum do povo e essencial à sadia qualidade de vida, impondo-se ao Poder Público e à coletividade o dever de defendê-lo e preservá-lo para as presentes e futuras gerações.". Portanto, as lentes da segurança pública, ora gravitam na seara da preservação da ordem, ora na preservação da incolumidade pública, como demonstrado por Oliveira (2017, p. 62), na proposição do círculo de interseção da segurança pública e do direito ambiental, ipsis:

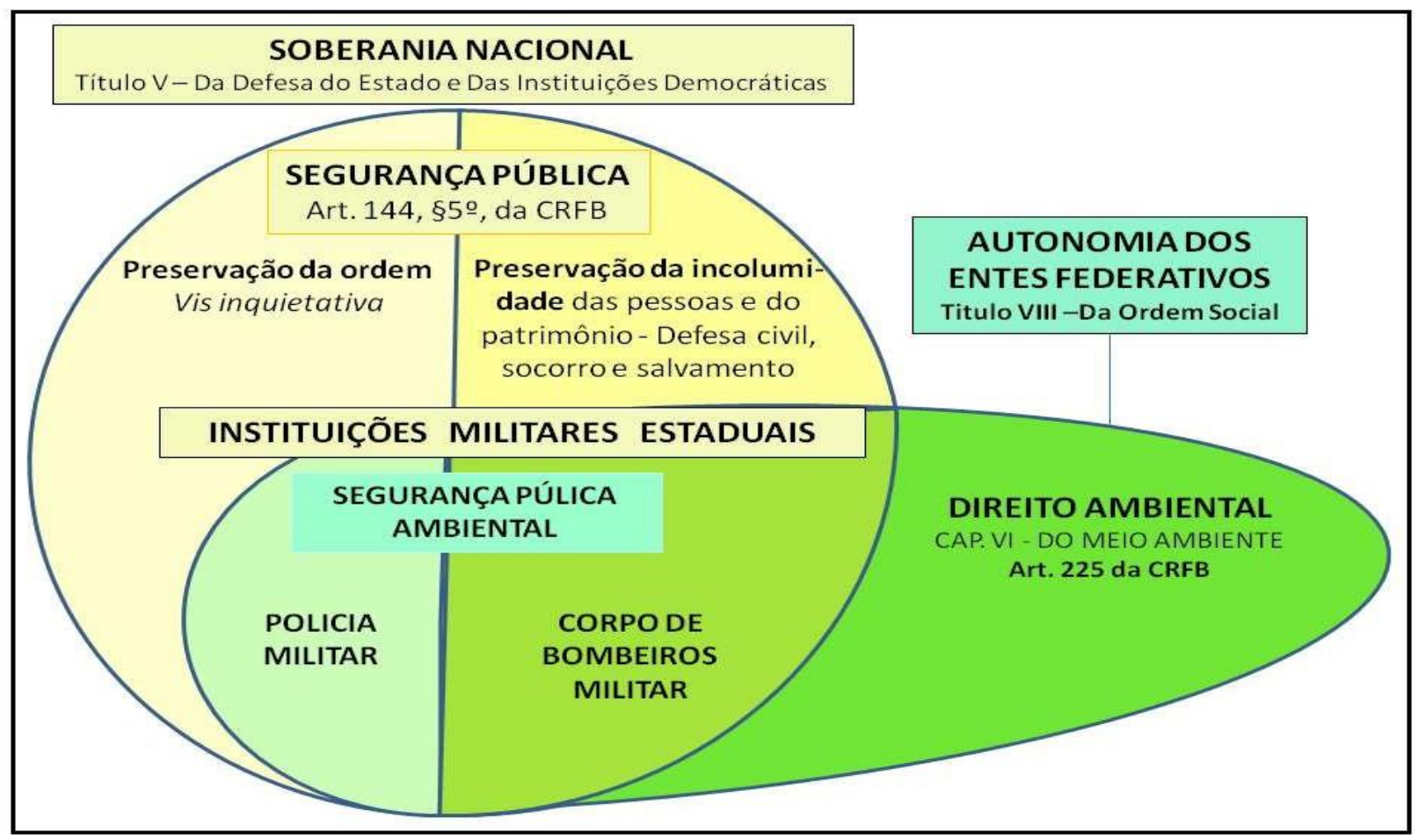

FIGURA 1 - Simbiose aprovada pela respectiva banca de dissertação (OLIVEIRA, 2017, p. 62)

Nas atribuições afetas aos Corpos de Bombeiros Militares - CBM. Há registro também, em conflito de competência, ao exercício de atividades de preservação da incolumidade pública das pessoas e do patrimônio entre o CBM e instituições de bombeiros civis ou análogos, e até órgãos ambientais, a exemplo do licenciamento de Mineradoras, atestando segurança pública, em confronto direto às atribuições constitucionais, inclusive por inferências de leis, contrariando a superlatividade da Lei Maior (BRASIL, 1988). O fato concreto ocorrido no Arraial de Bento Rodrigues, com "Lama até o pescoço", do Greenpeace (2015), primeira localidade atingida, verifica-se falha no sistema oportuno de "alerta". A aprovação pelos órgãos ambientais sem a aprovação pelos respectivos órgãos de 
segurança pública, implica desvio de finalidade e resultantes catastróficas, conforme a amostragem da imagem infra:

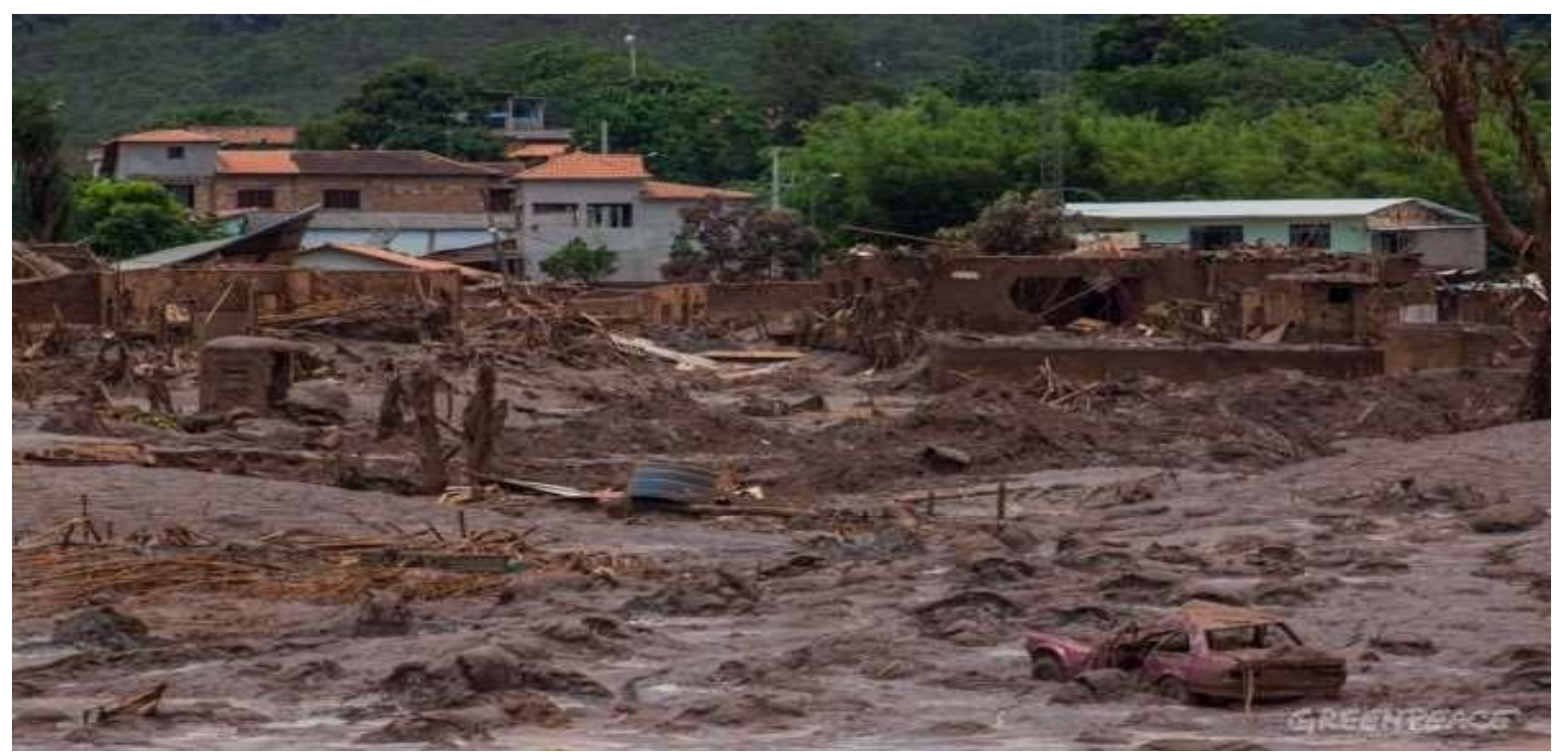

FIGURA 2 - Imagem após o escoamento de rejeitos da barragem de Fundão [Vista do arraial de Bento Rodrigues (@Victor Moriyama/Granpreace)].

Observa-se, ainda, que, diante da requisição da prestação estatal, independente de áreas limítrofes, tanto as IME's como a Polícia Civil devem atuar de forma integrada e mantendo relação de cordialidade. Perante a situação de urgência ou emergência, devem atuar incontinenti, mesmo no caso de supostas dúvidas ou restrições de caráter circunscricional, pois a atividade decorre da soberania, ou seja, de interesse nacional, cabendo as oportunas comunicações consentâneas. A inteligência teleológica da segurança pública é a prestação uniforme e homogênea no território nacional, apesar da desconcentração (à autonomia dos Estados -membros), reitera-se, que não retira a titularidade da União.

\section{A GÊNESE DAS IME'S E DA POLÍCIA CIVIL}

No contexto da demanda de segurança pública, às diligências de Rocha (2014, 1-5), todos os povos, em todos os tempos, contaram com grupos encarregados de manutenção da ordem social. $\mathrm{Na}$ antiguidade clássica a origem das polícias civis e militares se deu na França medieval, com a natureza predominantemente militar: 
No curso do tempo, essa polícia uniformizada de natureza militar deixou de ser uma força policial do exército francês para tornar-se uma polícia de preservação da ordem pública, com sua competência ampliada para além dos crimes praticados por militares nas estradas, passando a garantir a paz pública no reino através do policiamento preventivo, da investigação e do julgamento dos salteadores, ladrões e assassinos que aterrorizaram a zona rural e escapavam dos tribunais das cidades.

Conforme o autor, na França moderna, prevalecem duas corporações policiais, quais sejam: a Gendarmerie Nationale, que é militar; e a Polícia Nacional, de caráter civil, apesar da introjeção de algumas características militares, seja pelo uso de uniformes e emprego da nomenclatura militar para designação de alguns cargos. Ambas as instituições são autônomas e exercendo o ciclo completo de polícia.

O paradigma dual francês, segundo Rocha (2014, p. 4), foi irradiado para vários outros países, dentre os quais: a Arma dei Carabinieri di Itália, considerada a quarta força armada da Itália e uma de suas cinco forças de segurança; a Guardia Civil da Espanha, que é militar; a Guarda Nacional Republicana de Portugal, origem na Guarda Real da Polícia de Lisboa, em 1801. Este modelo lusitano foi a herança da Divisão Militar da Guarda Real de Polícia do Rio de Janeiro, inaugurando a polícia ostensiva fardada a partir da chegada da Família Real Portuguesa. Esta corporação deu origem à Polícia Militar do Estado do Rio de Janeiro e do Distrito Federal.

Na América do Sul, ainda, conforme Rocha (2014, p.4), foram instituídas as gendarmarias os Carabineros de Chile e a Gendarmería Nacional Argentina. Já na Europa, destacam-se a Força de Gendarmaria Européia (EUROGENDFOR ou EGF), que é integrada pelas seguintes corporações militares: Guarda Nacional Republicana (Portugal), Guardia Civil(Espanha), Gendarmerie Nationale (França), Arma dei Carabinieri (Itália), Koninklijke Marechaussee (Real Polícia Militar da Holanda) e Jandarmeria Româna (Romênia), dentre outras como a Turquia que se apresentou na EUROGENDFOR, por via da Jandarma Genel Komutanligi (Comando-Geral da Gendarmaria), a Polônia e a Lituânia, parceiras da Żandarmeria Wojskowa (Gendarmaria Militar) e do Lietuvos Viešojo Saugumo Tarnyba (Serviço de Segurança Pública Lituano).

Outro fator preponderante esclarecido por Rocha $(2014$, p. 5) é que os países anglosaxônicos, com rejeição ao modelo Francês, orientaram-se pela Polícia Civil ou paramilitar, embora uniformizada e com princípios hierárquicos. Em alguns países, como o Reino Unido, Estados Unidos e a Alemanha, esta última, possivelmente, por rejeição dogmática ao regime nazista, não adotam a polícia militar, exercendo o ciclo completo de policiamento, desde o ostensivo-preventivo até o investigativo-repressivo. 
Numa proposição de similaridade e convergência de propósitos, estrutura organizacional e performance, Campbeli e Campbelli (2014), no artigo intitulado: "Police/military convergence in the USA as organisational mimicry", demonstram que ambas as instituições americanas evoluem gradual e permanentente, em respeito à segurança e soberania do povo. Não se vislumbra no arquétipo estadunidense nenhuma depreciação em relação ao paradigma francês. Conforme Weber (2004), com sua biografia militar e religiosa, o militarismo e a predominante estrutura do executivo estão fundamentadas predominantemente no modelo patriarcal, em sentido de que a figura do chefe da família, que busca recursos externos e emana diretrizes à subsistência da "casa" é o Pai (Comandante, Chefe de Polícia, Presidente, Governador...), enquanto a genitora é responsável pela administração interna e mediação das ordens superiores (representa o papel do subcomandante, subchefe, vicepresidente, vice-governador...). Assim, sucessivamente, prevalecem nas subdivisões internas do Estado, como os Órgãos: Maior ou autônomo - Secretaria de Estado, Médios ou superiores - Diretorias ou comandos operacionais, Menores ou subalternos - ou batalhões, e outras subdivisões internas: Seções, Companhias, subseções, Pelotões, guarnições grupos (DI PIETRO, p. 593). Há também, em menor escala o paradigma sacerdotal (celibato - desprovido da figuração do cônjuge), a exemplo da autonomia do Ministério Público e do Judiciário. Em todas essas estruturas existem hierarquia e responsabilidades pelos resultados e atos praticados, independendo de ser a instituição civil ou militar.

\section{CARACTERÍSTICAS DAS IME'S}

Enquanto a Polícia Civil atua nas atividades de polícia judiciária, as IME's são titulares da preservação da ordem e da incolumidade públicas, representando a força física do Estado, para atuações preventivas e emergentes, tendo suas organizações e profissionais características especiais. Corroborando a leitura semântica em destaque, propalou o administrativista Hely Lopes Meirelles (2004, p.460), ipsis:

Como acentuado, a EC. 18/98 alterou a denominação da Seção III do Capítulo VII do Título III da CR/88 (Constituição da República), para "DOS MILITARES DOS ESTADOS, DO DISTRITO FEDERAL E DOS TERRITÓRIOS", e deslocou o tratamento dos Militares das Forças Armadas para o Capítulo II do Título V. Deixaram de ser Servidores Públicos, sendo denominados de MILITARES". (Grifou-se)

A estrutura das IME's são regidas pelo estatuto pátrio, como aduz o $\operatorname{art}^{8}$. 4으, inciso II, alíneas a, b, arts. 20 e 23, da Lei n. 6.880 (BRASIL, 1980), bem como a definição de seus postos e

\footnotetext{
${ }^{8}$ Art. 40 São considerados reserva das Forças Armadas:

[...].

II - no seu conjunto:
}

a) as Polícias Militares; $\mathrm{e}$ 
graduações pelas disposições do Decreto-Lei n. 667 (BRASIL, 1969), e processo promocional, com prevalência e norte do princípio constitucional da hierarquia e disciplina, como orienta a Lei n. 5.821 (BRASIL, 1972), a exemplo desta uniformidade pleiteada, não estão sendo uniformemente observadas, o que, conforme o postulado de Weber (2004), geram-se dúvidas à isenção das comissões promocionais e reflexos de indignação à tropa, que podem inferir no tratamento do policial em contato com a sociedade civil. Assim, as instituições militares estaduais têm o dever de seguir o aludido norte das Forças Armadas, sob pena de desconstituição do regime militar, cabendo severidade nas supervisões do Exército Brasileiro às IME's. Por analogia, a definição de cargo prevista no art $^{9}$. 38 do EMEMG (MINAS GERAIS, 1969), não pode distanciar do balizamento da legislação federal. A definição de cargo, função e encargo no militarismo, conforme elucidou Oliveira (2017, p. 52), com fulcro no Decreto-Lei n. 667 (BRASIL, 1969), e postulado de Di Pietro (2014, p. 603), significam:

[...], que, no militarismo, mediante as equiparações conceituais, "cargo" equivale ao posto e graduação, enquanto as "funções" correspondem ao conjunto de atribuições constitucionais ordinárias inerentes ao ofício do cargo. Ainda, além destes peculiares conceitos, urgem os "encargos", que são atribuições eventuais e extraordinárias peculiares aos cargos (trabalhos comissionados, investigações administrativas designadas, dentre outros).

As IMe's, sine qua non, são estabelecidas em simbiose com os ditames estruturais de padronização e uniformidade às Forças Armadas, diferenciando-se dos demais órgãos civis. Em sentido análogo, demonstrando exemplificativamente o explícito tratamento constitucional diferenciado confirma o José Afonso Silva (2013, p. 712),:

A EC-18/98 modificou a Seç. III do Cap. VII do Tít. III da Constituição, que compreendia e compreende apenas o art. 42. Determinou que a rubrica da [...].

b) os Corpos de Bombeiros Militares.

Art. 20. Cargo militar é um conjunto de atribuições, deveres e responsabilidades cometidos a um militar em serviço ativo.

$\S 1$ 으 0 cargo militar, a que se refere este artigo, é o que se encontra especificado nos Quadros de Efetivo ou Tabelas de Lotação das Forças Armadas ou previsto, caracterizado ou definido como tal em outras disposições legais.

$[\ldots]$.

Art. 23. Função militar é o exercício das obrigações inerentes ao cargo militar.

${ }^{9}$ Art. 38 - São adotadas as seguintes definições:

I - cargo é o conjunto de atribuições definidas por lei ou regulamento e cometido, em caráter permanente, a um militar;

II - encargo é a atribuição de serviço cometida a um militar;

III - função ou exercício é a execução, dentro das normas regulamentares, das atribuições estipuladas para os cargos e encargos; [...]. 
seção, que era Dos Servidores Públicos Militares passasse a ser: Dos Militares dos Estados, do Distrito Federal e dos Territórios. Retirou do art. 42 a matéria referente aos militares das Forças Armadas, transferindo-a para o §3으 do.art. 142 , acrescentado por aquela emenda. A intenção confessada foi a de tirar dos militares o conceito de servidores públicos que a Constituiçao Ihes dava, visando com isso fugir ao vínculo aos servidores civis que esta lhes impunha. Formalmente, deixaram de ser conceituados como militares. Com isso, aliás, reforçou a característica militarista das Polícias Militares num momento em que parcela ponderável da sociedade busca desvinculá-las dessa conceituação. Ontologicamente, porém, nada mudou porque os militares são, sim, servidores públicos em sentido amplo como eram considerados na regra constitucional reformada. São agentes públicos, como qualquer outro prestador de serviço ao Estado. A diferença é que agora se pode separar as duas categorias, em lugar de servidores civis e servidores militares, embora assim sejam, em agentes públicos administrativos e agentes públicos militares. Contudo, a EC-19/98 reenquadrou ainda que indiretamente, os policiais militares no conceito de servidores, ao afirmar que a remuneração dos servidores policiais militares será fixada na forma de subsídio, segundo o previsto no art. 39, § 4ํ, da Constituição.

Doutrinariamente, as IME's estão respaldadas na coleção milenar de experiências e saberes, à sedimentação de conhecimentos, uniformidade de linguagem e comportamento, evoluções metodológicas e de princípios próprios da caserna (OLIVEIRA, 2017, p. 49, 50; ROSA e BRITO (2010, p. 209, 2010). Assim, o apanágio militar é gravado de técnicas e táticas estabelecidas também no contexto científico (decorrente até mesmo do aperfeiçoamento empírico de sucessivos erros e acertos), à eficiência organizacional administrativa e operacional. Para tanto, as IME's adotam o paradigmas de uniformidade de tropa, vestuários e manobras grupais ou individuais sincronizadas, destacando a "automatização de movimentos e comandos de grande número de soldados em determinada localização, sob a regência da hierarquia e disciplina.

A CRFB (BRASIL, 1988), recepcionando o estatuto pátrio (Brasil, 1980) e o Decreto-Lei n. 667 (BRASIL, 1969), destacou a finalidade e nível de competência das IME's como longa manus do Exército Brasileiro. Destarte, como forças auxiliares, as IME's atuam subsidiariamente em caso de mobilização nacional ou de guerra, conforme ditame do §60, do art. 144, que assevera: “§60 - As polícias militares e corpos de bombeiros militares, forças auxiliares e reserva do Exército, subordinam-se, juntamente com as polícias civis, aos Governadores dos Estados, do Distrito Federal e dos Territórios." (grifou-se). Em síntese, consolidando as atinentes características, precomizam os arts. 42 e 142 da CRFB (BRASIL, 1988):

Art. 42 Os membros das Polícias Militares e Corpos de Bombeiros Militares, instituições organizadas com base na hierarquia e disciplina, são militares dos Estados, do Distrito Federal e dos Territórios. 
$\S 1$ 1 Aplicam-se aos militares dos Estados, do Distrito Federal e dos Territórios, além do que vier a ser fixado em lei, as disposições do art. 14, § 8ㅇ; do art. 40, § 9o; e do art. 142, $\S \S 20$ e 3ㅇ, cabendo a lei estadual específica dispor sobre as matérias do art. 142, §3, inciso $X$, sendo as patentes dos oficiais conferidas pelos respectivos governadores.

[...].

Art. 142. As Forças Armadas [...].

[...].

§ 3 응 Os membros das Forças Armadas são denominados militares, aplicando-seIhes, além das que vierem a ser fixadas em lei, as seguintes disposições:

$[\ldots]$;

VII - o oficial condenado na justiça comum ou militar a pena privativa de liberdade superior a dois anos, por sentença transitada em julgado, será submetido ao julgamento previsto no inciso anterior;

VIII - aplica-se aos militares o disposto no art. 7으, incisos VIII, XII, XVII, XVIII, XIX e XXV e no art. 37, incisos XI, XIII, XIV e XV; [...]. (Grifou-se)

As IME's, diferentemente dos demais órgãos de Estado (civis), ad exemplus, são as únicas instituições que não gozam, sequer, de nenhuma hipótese de pessoalidade administrativa. A única flexibilidade do princípio da impessoalidade prevista constitucionalmente está gravada no inciso $\mathrm{V}$, do art. 37 da CRFB (BRASIL, 1988) e não se aplica às IME's. O dispositivo invocado permite, por livre escolha do Administrador, a indicação de pessoas de confiança para a ocupação de cargos e funções de direção, chefia ou assessoramento.

Consoante a taxatividade do princípio da legalidade, em sentido amplo, e combinação do inc. VIII, do §3으, do art. 142, por remessa do §1ㅇ do art. 42, todos da CRFB (BRASIL, 1988), aos militares, no que dispõem o art. 37, às IME's, aplicam-se apenas os inc. XI, XIII, XIV e XV. Logicamente, não admitindo situação contrária, pois também estaria sendo violado princípio da hierarquia e disciplina, inserto no caput do art. 42, como a base da administração militar. Por conseguinte, a aplicação ilustrada do inc. V, seria incentivo ao nepotismo, assedio moral e ruína da Corporação. A inteligência constitucional promulga, previne e inibe a possibilidade de formação, ad exemplus, de um soldado "traidor" (apadrinhado ou assediado, moldado por mazelas, ou até mesmo injustiçado, indignado e irado), mutatis mutandis, levando e trazendo informações a grupos dissidentes, para o fracasso ou destruição da Casa.

\section{DO PERFIL PROFISSIOGRÁFICO DOS PROFISSIONAIS DE SEGURANÇA PÚBLICA}

Holisticamente, seja com fulcro nos módulos de produção industrial, quer na prestação do serviço público, os homens designados para representar as respectivas instituições, no mínimo aderiram os termos estabelecidos (em contratos ou editais). Para o serviço público de segurança pública, os selecionados e aprovados em concurso e curso de formação específico, devem despir-se 
da subjetividade e emoções. Como aduziu Weber (2004, p. 101, 244), os aludidos profissionais devem ser "déspotas" (sem coração ou paixão), que, cumprindo a lei, automaticamente estarão contemplando os requisitos mínimos de equilíbrio, honestidade, justiça, polidez, respeito, dentre outros atributos indispensáveis à volição do art. 5o e caput do art. 37 da CRFB (BRASIL, 1988). Assim, aflora-se a preocupação weberiana (GODOI, 2008; PETRY, 2004; WEBER, 2004) e de Oliveira (2013, p. 17), propondo que "as organizações são diferentes por serem constituídas por homens, sendo os homens diferentes".

Nesse diapasão, justifica-se, portanto, a essencial regulação, seleção e controle comportamental. Um dos enfoques do perfil profissiográfico dos profissionais de segurança pública foi delineado em estudo afeto da Secretaria de Segurança Pública, do Ministério da Justiça (BRASIL, $2012)^{10}$, sendo previsto também no art. 1ํ, §3으, do Decreto n. 7.308 (BRASIL, 2010), na exigência de requisitos psicológicos para o desempenho eficiente das funções, propondo-se referenciais como: “[...] estudo científico das atribuições e responsabilidades dos cargos, descrição detalhada das atividades e tarefas, identificação dos conhecimentos, habilidades e características pessoais necessários para sua execução e identificação de características restritivas ou impeditivas para o cargo.". Nesta mesma consistência, propalaram Faiad et. al. (2012, p. 393, 394):

Diante disso, o perfil profissiográfico se tornou uma das ferramentas mais utilizadas para seleção e formação de policiais no Brasil, representando mais do que a simples descrição de cargos e funções dentro da organização. Por meio da análise profissiográfica, obtém-se um estudo detalhado de todas as tarefas de um determinado cargo ou função, com especificação do nível de dificuldade, importância e frequência com que elas ocorrem. Nesse sentido, serve como instrumento auxiliar não só no processo seletivo como também no curso de formação, na medida em que possibilita a determinação dos aspectos mínimos a serem abordados nas disciplinas ministradas para busca do policial que mais se aproxime do exigido pela instituição e pela sociedade.

Outro fator preponderante às funções atribuídas aos cargos militares emerge da capacidade laborativa predominante de gestão aos oficiais e execução aos graduados, conforme imperam os arts ${ }^{11}, 36$ a 38 do estatuto pátrio (BRASIL 1980), à inferência ainda do timoneiro Código

\footnotetext{
${ }^{10} \mathrm{~A}$ metodologia de análise profissiográfica contribui com um estudo sistemático de todo o processo de trabalho referente a cada cargo de uma instituição. Consiste em uma metodologia utilizada para o levantamento do perfil profissiográfico de um determinado cargo, ou seja, uma análise detalhada de suas características e necessidades, a partir de uma amostra representativa de grande parte da população ocupante do cargo analisado. (BRASIL, 2012, p. 11)

${ }^{11}$ Art. 36. O oficial é preparado, ao longo da carreira, para o exercício de funções de comando, de chefia e de direção.

Art. 37. Os graduados auxiliam ou complementam as atividades dos oficiais, quer no adestramento e no emprego de meios, quer na instrução e na administração.

[...].
} 
Penal Militar (BRASIL, 1969) que, nesta exegese contemplativa, preconiza: "Art. 132. No crime de deserção, embora decorrido o prazo da prescrição, esta só extingue a punibilidade quando o desertor atinge a idade de quarenta e cinco anos, e, se oficial, a de sessenta" (grifos nossos). Desta feita, de acordo com a complexidade das tarefas, o tempo de serviço e a eficiência da capacidade laborativa são relativos, pois os oficiais, nas atividades predominantes de gestão, ou seja, intelecto-mental, podem ser aproveitados por mais tempo na Corporação, enquanto às praças, na atividade de execução da segurança pública, caracterizado pela demanda de habilidade e robustez física, até mesmo pela responsabilidade objetiva do Estado, seu tempo de aposentadoria deve ser proporcionalizado.

O militar estadual, por sua vez, é um "servidor público especial", admitido por rígido concurso público e curso de formação, com a condicionante resignação e adesão ao regime estatutário (SILVA, 2013, p. 785; Di Pietro, 2014, p. 603), como esclarece também Martins (1996, p. 26 e 62), in verbis:

1. Já nos ocupamos no tópico anterior das peculiaridades da disciplina militar, donde concluímos ser a disciplina do militar "qualificada", na medida em que deste servidor público espera-se mais do que a disciplina mediana, um "plus", conforme aludimos.

2. Ora, sem pretender voltar à questão que já ventilamos em passagem anterior, são notórios que os militares são servidores públicos especiais. Como já discorremos, o próprio papel institucional desta categoria de servidores impõeIhe trato diferenciado. Assim, se dos servidores públicos civis espera-se no mais das vezes regularidade de serviços, como já apontamos, dos servidores públicos militares espera-se uma certa adesão psicológica aos fins, preceitos, tradição e princípios de suas instituições.

A automatização desses valores inerentes ao perfil profissiográfico e à capacidade laborativa do militar, inerente aos cargos e funções (arts. 20, 23, 36 a 38 da Lei n. 6.880, BRASIL, 1980), decorre, ainda, da bagagem de requisitos mínimos de ingresso na Corporação (nível de escolaridade, saúde física e mental) e da formação nos bancos escolares de recrutamento na Corporação, como aduz Rosa e Brito (2010, p. 209):

As consequências dessa alternação emergem na forma como os militares exteriorizam seus julgamentos e na forma como utilizam seus corpos; este uso do corpo assume caráter performático, pois deve operá-lo como arma, tendo em vista a missão bélica que norteia a organização. No entanto, o grau de belicosidade desse corpo, bem como o grau de inCorporação dessa lógica, depende da intensidade e da duração com que este corpo é trabalhado, ou seja,

Art. 38. Os Cabos, Taifeiros-Mores, Soldados-de-Primeira-Classe, Taifeiros-de-Primeira-Classe, Marinheiros, Soldados, Soldados-de-Segunda-Classe e Taifeiros-de-Segunda-Classe são, essencialmente, elementos de execução. 
o tipo de construção que esse corpo sofre durante a fase de formação militar nos diversos estabelecimentos de ensino (grifo do autor).

No militarismo e também na Polícia Civil, o treinamento é essencial para atuação no complexo e oportuno mosaico de conflitos pessoais, vinculando ocorrências de diversas naturezas. Estas Instituições, conforme narrativa de Silva (2013, p. 713), em situação análoga à das escolas de governo, os cursos são dinamizados em ambiente escolar próprio, sendo que a matrícula não implica a confirmação do ingresso, mas a aprovação no curso de formação específico. Nesta ótica já recomendava Weber (2004, p. 529):

Do mesmo modo que o chamado progresso em direção ao capitalismo, desde a Idade Média, é o critério unívoco da modernização da economia, o progresso em direção ao funcionalismo burocrático, baseado em contrato, salário, pensão, carreira, treinamento especializado e divisão de trabalho, competências fixas, documentação e ordem hierárquica, é o critério igualmente unívoco da modernização do Estado, tanto do monárquico quanto do democrático.

Conforme a exposição de Weber (2004, p. 210. 211), que, segundo Godoi $(2008$, p.2) e Petry (2004, p. 14), na década de 1880, prestou serviço militar ao exército imperial, como soldado e recebendo o título de oficial, a seleção dos profissionais de segurança pública foca não só a robustez física e higidez mental, mas também a intelectualidade. A segurança pública evidencia proteção e garantia dos direitos humanos, aguçando o exercício constante do pensamento reflexivo e da axiologia jurídica (ALEXY, 2005, 2011), em face das exigências e controvérsias peculiares à modernidade, além de serem titulares do exercício da polícia judiciária. Portanto, nestas tarefas não se admitem deficientes físicos, primeiro no tocante a responsabilidade objetiva do Estado em relação às limitações desses servidores, em segundo pelos rigores regulamentares e exacerbado estresse peculiar das atividades da caserna, que, ao contrário da proposição social de reintegração, geraria constrangimentos e sérios prejuízos à qualidade de vida dos aludidos. Ambos os casos motivam ainda a redução do número de vagas do sexo feminino nas Corporações. Destarte, é estratégico e diferenciado o perfil profissiográfico dos profissionais de segurança pública.

$\mathrm{Na}$ assertiva da intelectualidade formal, o universo seletivos é satisfatório à exigência de nível superior de escolaridade, mas observando que, o processo de recrutamento e seleção das corporações, como já aludido, são realizados em três fases, prova teórica, testes de aptidão física e mental e ainda o curso de formação. Só depois da aprovação final no respectivo curso é que, realmente haverá a efetivação do cargo. Nesta senda, verifica-se a possibilidade do candidato apresentar o certificado de conclusão do curso superior oportunamente, cabendo aos editais preverem a compatibilidade periódica. 
Em ratificação à temática, pesquisas estatísticas desse universo seletivo, a exemplo do Portal Brasil (EM NOVE..., 2014) apontam que: entre os anos de 2003 (8,1\%) e 2013 (15,1\%), praticamente foi duplicado o percentual anual de pessoas entre 25 e 29 anos com nível superior, sendo que, em 2013, 55\% dos estudantes entre 18 e 24 anos estavam frequentando cursos superiores. Uma das premissas de maximização da eficiência e da qualidade do serviço público têm sido o incentivo e a exigência do conhecimento técnico superior como requisito de adequação à capacidade laborativa e

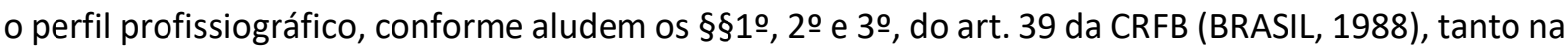
fase de gestão, quanto nas tarefas de execução operacional, mediante a ampla expansão da formação universitária, como também respeito aos usuários do serviço em tela.

\section{PROPOSTAS DE DESMILITARIZAÇÃO}

As pesquisas focadas no objeto da desmilitarização das IME's e unificação das polícias foram protocoladas em vários episódios na Câmara Federal. Conforme Rocha (2011, p.35-37) foram protocolados vários Projetos de Emenda à Constituição (PEC), vinculadas à proposição de desmilitarização, dentre as quais destacaram-se a PEC 46/1991, Deputado Hélio Bicudo (PT/SP), PEC 151/1995, do Deputado Gonzaga Patriota (PSB/PE); PEC 514/1997, do Poder Executivo; PEC 613/1998, da Deputada Zulaiê Cobra (PSDB/SP); PEC 534/2002 do Senado Federal (Senador Romeu Tuma, PFL/SP); PEC 181/2003, do Deputado Josias Quintal (PMDB/RJ); PEC 496/2002, do Deputado Aloizio Mercadante (PT/SP); PEC 21/2005, do Senador Tasso Jereissati (PSDB/CE); PEC 589/2006, do Deputado Ricardo Santos (PSDB/ES); PEC 143/2007, do Deputado Edmar Moreira (DEM/MG), PEC 430/2009, do Deputado Celso Russomano (PP/SP). As primeiras delas, surgiram logo após a queda do Governo Militar, momento político acalorado e conturbado, presumindo a possibilidade contaminação por parte das esferas interessadas, conforme ilustrou MARCHI (2010, p. 120):

[...] Vale dizer, que nem mesmo os Presidentes Militares, no período da ditadura em nosso País, ousaram tamanha aberração jurídica. Tramita, entretanto, a Proposta de Emenda Constitucional 613/98, da Deputada Zulaiê Cobra, a qual foi apensada na PEC 151/95, versando sobre a reestruturação do Sistema Policial Brasileiro e Criação do Sistema de Defesa Civil. Na referida Proposta de Emenda Constitucional, a parlamentar pretende "uma polícia cidadã para a segurança pública da cidadania".

A Ordem dos Advogados do Brasil (OAB, 1994), na Conferência Nacional da OAB, em Foz do Iguaçu, no período de 4 a 8 de setembro, aprovaram uma "Proposta para uma Nova Política de 
Segurança Pública", na qual, em defesa da desmilitarização da polícia preventivo-ostensiva, elencou as seguintes premissas:

[...] as razões de tal circunstância remontam à história da corporação que é considerada força auxiliar e reserva do Exército. É sabido que durante a ditadura (1964-1985), a Polícia Militar atuou na repressão política e assimilou, radicalmente, a ideologia da segurança nacional.

[...] o resultado é o despreparo da Polícia Militar para atuar ao lado da população, como um serviço social, equiparado aos serviços de saúde e educação, e destinada à proteção da vida e do patrimônio.

De fato, a natureza do serviço policial é essencialmente civil, devendo obediência aos princípios da legalidade, impessoalidade, moralidade e publicidade, os quais, de resto, obrigam todos os ramos de atuação da administração pública.

Nenhum motivo existe, com efeito, que justifique a manutenção de uma polícia militarizada para a prestação do serviço de segurança pública.

[...] quanto à uniformização, à disciplina e à hierarquia, é fato já muitas vezes sublinhado que não são prerrogativas exclusivamente militares. Nada impede que uma polícia civil incumbida de policiamento preventivo ostensivo seja uniformizada e organizada hierarquicamente. Apenas, reserve-se a natureza militar aos membros das Forças Armadas - Marinha, Exército e Aeronáutica.

Promovendo pesquisas a respeito, a deputada federal Zulair Cobra (1998), após os resultados obtidos nos âmbitos federal e estadual, acerca do policiamento brasileiro, mediou e elaborou um dos mais inflamados projetos de desmilitarização, todavia desprovido de avaliações das raízes históricas de gênese no consagrado e instaurado modelo francês da Gendarmerie Nationale. 0 trabalho em epígrafe foi escudado nas seguintes razões:

a) sucateamento dos equipamentos e inadequação do armamento utilizado pelo policial, em confronto com o armamento utilizado pelos criminosos;

b) falta de integração e coordenação entre as duas polícias estaduais;

c) dualidade dos Órgãos de Segurança Pública, como fator de redução de eficiência;

d) inadequação ao regime militar para a polícia ostensiva;

e) incompatibilidade entre as atribuições cometidas aos Corpos de Bombeiros e o seu enquadramento como órgão de Segurança Pública;

f) inexistência de autonomia e de recursos adequados para a área técnica da polícia civil: perícia, identificação criminal e medicina-legal;

g) falta de integração regional dos órgãos de Segurança Pública.

Em polo contrário, propondo a permanência do estado de coisas entre a polícia civil e polícia militar, cada qual com suas atribuições específicas, entretanto, também sem avaliar o fundo histórico da gênese, finalidade e resultados dos paradigmas anglo-saxônico ou francês, os argumentos em defesa do militarismo alicerçaram-se nas seguintes premissas: 
a) a condição militar da polícia ostensiva é histórica, tendo suas raízes nos tempos imperiais;

b) somente sob o regime militar, fundado na hierarquia e na disciplina, é possível manter-se sob controle um efetivo armado da magnitude que as Polícias Militares possuem nos diferentes Estados (por exemplo, em São Paulo, seu efetivo atinge cerca de oitenta mil homens);

c) o regime militar permite que o Estado tenha o policial ostensivo vinte e quatro horas por dia à sua disposição, sem que isso signifique ônus financeiro adicional, tendo em vista que os militares não tem direito a horas extras;

d) somente sob regime militar assegura-se que o policial não irá recuar diante dos riscos do enfrentamento com os criminosos;

e) a proibição de sindicalização e greve, imposta aos militares, garante a continuidade desse serviço essencial; [...].

Sintetizando os posicionamentos favoráveis à desmilitarização e unificação de pessoal, na mesma linha, Zulair Cobra (1998), em consonância e fusão dos argumentos sedimentados nas propostas originárias da OAB e PEC 46/91, demonstrando discurso político pós-quebra do regime militar, sem cientificidade e desprovido de razões técnicas, asseverou:

a) a atividade policial é essencialmente civil, havendo incompatibilidade entre a concepção militar de "destruir o inimigo" e a atividade policial de proteger o cidadão;

b) o regime militar em nada melhora a qualidade dos serviços prestados pelo policial, uma vez que o rígido sistema hierárquico e o regime disciplinar que lhe é imposto não têm reflexos na sua ação junto à sociedade;

c) a jornada de trabalho dos policiais militares, sem uma contrapartida salarial, é fonte de desestímulo profissional e incentiva o trabalho paralelo - o chamado "bico" -, o que prejudica ainda mais os serviços oferecidos à população;

d) a condição de militar assegura ao policial um foro privilegiado que acaba se constituindo em um fator que favorece a impunidade do policial que comete excessos contra a população.

[...]. Assim, dos argumentos apresentados, entendeu-se que o merecedor da análise mais detalhada deveria ser o da incompatibilidade entre a atividade policial, que é civil, e a concepção de emprego militar, que visa a "destruir o inimigo".

Diante dos diversos projetos tramitados nas respectivas casas legislativas, as respectivas consultorias emitiram pareceres, dentre os quais, os mais recentes e próximos acumulam fatores da realidade moderna insertos na proposição da PEC 51 (BRASIL, 2013). Dentre as fundamentações exaradas, destacaram-se:

Avaliando o fomento de censura social às polícias, para melhor compreensão temática, Rocha, (2014, p.21) descreveu a repercussão fática de alguns eventos divulgados pela mídia, mencionando as Policias Civis de São Paulo e do Rio de Janeiro como itinerantes, na década de 1960, na "eliminação de bandidos", como forma de retaliação e vingança pela morte de companheiros e 
controle da criminalidade, sob a aprovação de $70 \%$ da população de São Paulo e maior parte da população do Rio, onde surgiu a expressão: "bandido bom é bandido morto". Acrescentou ainda, com base em suas pesquisas, que com a retirada dos policiais civis das ruas e assunção da polícia militar, alguns destes absorveram o modus operandi daqueles, maculando a corporação. Neste sentido reverberou:

Desde então, em face da percepção de que as leis e o Poder Judiciário são impotentes para responder aos anseios de uma sociedade amedrontada e acuada diante dos crescentes índices da criminalidade, de que a Polícia Civil não consegue conduzir as investigações com eficiência, deixando que os delinquentes escapem livres e prossigam em suas carreiras criminosas, e de que o sistema penitenciário se constitui em locus para o aperfeiçoamento e articulações mais avançadas da criminalidade, em facções cada vez mais organizadas e violentas e que já se sentem mais fortes do que o Estado, desafiando-o, aumentaram as apostas na justiça sumária pelas mãos de policiais e por esquadrões da morte, grupos de extermínio e justiceiros.

A conceituação de alguns defensores da desmilitarização sugere paradoxos, a exemplo da lição de Lima e Oliveira (2016, p.96), não proporcionando a fluência de um discurso dialético, mas predominantemente retórico e antiético (considerando a falta de legitimidade e ao mesmo tempo o constrangimento de intervir em outras "casas"), sem dados científicos ou sociais, nem mesmo refutando motivadamente a funcionalidade do consagrado e pioneiro modelo francês, afirmando o militarismo como causa de violência ativa e não reativa:

O militarismo tem como alicerces ideológicos três pilares rígidos, quais sejam: a hierarquia, a disciplina e a existência de um inimigo a ser combatido. Embora essa forma de organização faça algum sentido para a defesa da soberania de um país, por meio de suas forças armadas, é inconcebível para a segurança pública interna num Estado Democrático de Direito, uma vez que é totalmente incompatível com a defesa de direitos humanos.

Examinando a conjuntura histórica de fatos sucessivos, Rocha (2014, p.22), vislumbra mazelas corporativas que são inerentes ao "homem contaminado", por fatores culturais do "lugar" ou "mundo da vida", não representa característica específica de quaisquer das instituições de segurança pública. Assim, empregando o raciocínio lógico solapa, em sincronismo às reflexões de Habermas (1992, p.299), os argumentos de cunho "ético", em favor da isenção e amplitude "moral":

Portanto, a letalidade da Polícia Militar não resultou da sua militarização durante os governos militares nem é herança da ideologia da segurança nacional, como querem alguns. Por tudo isso, há de se perceber no tipo de missão e nas circunstâncias a serem enfrentadas, e não a natureza militar, a razão das alegadas violência e letalidade das Polícias Militares. 
Fosse a natureza militar a razão, os Corpos de Bombeiros Militares seriam igualmente violentos e letais. Também os estabelecimentos de ensino militares, desde os Colégios Militares até os estabelecimentos superiores de ensino e pesquisa seriam locus de violência e letalidade, e não os centros de excelência de formação intelectual que demonstram ser.

Complementando o raciocínio lógico, por silogismo, Rocha (2014, p.22), compara a relação da formação militar e resultados auferidos em outros quesitos, demonstrando proposições sofísticas. Uma ilustração de destaque demonstrada é a formação padronizada dos bombeiros militares em relação à polícia militar, que pode ser vislumbrada na ocupação dos melhores Índices de Confiança Social - ICS do País (IBOPE, 2014), por vários anos, entretanto, a confiança pode não estar vinculada a resultados satisfatórios concretos, mas a nobreza da atividade, suscitando a fragilidade das premissas em favor da desmilitarização:

A formação militar não pode se confundir com a natureza das missões que serão executadas. Aquela precede estas. $O$ bombeiro militar tem formação militar e irá combater o fogo. O soldado de Infantaria tem formação militar e irá combater o inimigo. O médico militar e o soldado padioleiro têm formação militar e irão salvar vidas, até do inimigo, se necessário for. O policial militar tem formação militar e irá enfrentar os infratores da lei. Há o militar de guerra. Há o militar de polícia.

A formação militar pressupõe a assimilação de valores que envolvem o sentimento do dever a ser cumprido, o culto à hierarquia e disciplina, a obediência às ordens recebidas e ao ordenamento jurídico, ética, civismo, tudo se materializando em ritos, solenidades, formalismos, gestos e atitudes que são muito próprios dessa formação.

Exteriorizando conflitos éticos, entre profissionais de "casas" autônomas (ética), o cenário destaca ataques e defesas mútuas de instituições diferentes, em prejuízo da integridade do corpo estatal, sem resultar no genuíno discurso moral, com repouso em razões isentas e de maior consistência científica à pacificação das pretensas controvérsias. Algumas instituições classistas tomam iniciativas em matérias afetas à casa alheia, sugerindo violação ética e moral, conforme o paradigma de Habermas (2003).

Num enfoque científico, Rocha (2014, p.28,29), na lavra de seu parecer jurídico pela Câmara dos Deputados, promovendo o discurso dialético para avaliar as inúmeras propostas de modificações, como a desmilitarização, unificação das polícias, e demais assertivas desta pasta, para, então, confirmá-las ou subjulgá-las, inclusive suscitando propostas de racionalização às respectivas atividades-fim:

Todavia, tudo indica que as taxas de atrito entre as Polícias Militares e as Polícias Civis foram consideravelmente reduzidas na exata medida em que cada 
corporação foi melhor compreendendo as suas atribuições e respeitando as fronteiras delimitadas para a atuação de cada uma.

Mesmo assim, não faltam exemplos de Serviços Reservados das Polícias Militares investigando além dos muros das suas respectivas corporações e de Polícias Civis empregando veículos com luzes e pinturas ostensivas e grupos utilizando uniformes, não poucas vezes militarizados, e símbolos de suas corporações.

A própria Polícia Civil é desviada da sua atividade-fim quando se vê obrigada a despender pessoal, tempo e recursos com o registro de acidentes de trânsito sem vítimas ou de documentos e cheques perdidos.

E sobreposição por sobreposição, ela existe, e muito maior, entre a Polícia Civil e o Poder Judiciário, quando, neste, são repetidos, no curso do processo, vários atos praticados durante o inquérito policial: oitivas, inquirições e produção de provas.

Nesse diapasão, apesar de vícios sistêmicos que transcendem a esfera da segurança pública (tais como o poder legislativo e judiciário), verifica-se a necessidade de racionalização de tarefas, evitando-se os desvios de finalidade (considerando que o desvio de função tem nova definição jurídica pela súmula 378 do STJ). Não se justifica, à resistente malha do caput do art. 37, da CRFB (BRASIL, 1988), esse status quo, de remanejamento de escasso e especializado de efetivo à atividades distantes da finalidade constitucional.

A conceituação de alguns defensores da desmilitarização sugere paradoxos, a exemplo Lima e Oliveira (2016, p.96), não proporcionando a fluência de um discurso dialético, mas predominantemente retórico, sem dados científicos ou sociais e sem refutar a funcionalidade do modelo francês, afirmando o militarismo como causa de violência ativa e não reativa:

O militarismo tem como alicerces ideológicos três pilares rígidos, quais sejam: a hierarquia, a disciplina e a existência de um inimigo a ser combatido. Embora essa forma de organização faça algum sentido para a defesa da soberania de um país, por meio de suas forças armadas, é inconcebível para a segurança pública interna num Estado Democrático de Direito, uma vez que é totalmente incompatível com a defesa de direitos humanos.

Exteriorizando conflitos éticos, entre profissionais das casas da polícia militar e da polícia civil, dentre outras, cada instituição se defendendo e velada e explicitamente atacando uma e outra, nesse sentido, acabam por abandonar o genuíno discurso moral, com razões isentas e com maior consistência científica. Algumas instituições classistas inclusive tomam iniciativas em matéria afeta a outras casas, sugerindo violação ética e moral, conforme o paradigma de Habermas (2003). Num enfoque científico, Rocha (2014, p.28, 29), na lavra de seu parecer jurídico, pela Câmara dos Deputados, promove o discurso dialético para avaliar as inúmeras propostas de modificações, como a 
desmilitarização, unificação das polícias, e demais assertivas desta pasta, para, então, confirmá-las ou solapá-las:

Todavia, tudo indica que as taxas de atrito entre as Polícias Militares e as Polícias Civis foram consideravelmente reduzidas na exata medida em que cada corporação foi melhor compreendendo as suas atribuições e respeitando as fronteiras delimitadas para a atuação de cada uma.

Mesmo assim, não faltam exemplos de Serviços Reservados das Polícias Militares investigando além dos muros das suas respectivas corporações e de Polícias Civis empregando veículos com luzes e pinturas ostensivas e grupos utilizando uniformes, não poucas vezes militarizados, e símbolos de suas corporações.

A própria Polícia Civil é desviada da sua atividade-fim quando se vê obrigada a despender pessoal, tempo e recursos com o registro de acidentes de trânsito sem vítimas ou de documentos e cheques perdidos.

E sobreposição por sobreposição, ela existe, e muito maior, entre a Polícia Civil e o Poder Judiciário, quando, neste, são repetidos, no curso do processo, vários atos praticados durante o inquérito policial: oitivas, inquirições e produção de provas.

As reflexões aguçadas por Rocha (2014, p.29-31) produziram várias incógnitas, contudo, várias delas essenciais e sugerindo respostas simples, mas correlatas ao nível de emprego da tecnologia e da burocracia administrativa na atualidade, especialmente no tocante à racionalidade comunicativa entre as instituições. Assim preconizou:

Qualquer dessas alternativas apresenta inúmeros problemas decorrentes: Qual seria a taxa de atrito entre os integrantes oriundos das diferentes polícias? Se alguma das corporações for extinta, o que fazer com os seus integrantes? As Polícias Civis seriam menos truculentas e letais realizando o policiamento ostensivo? E por aí vai.

[...]

E qual será o custo do processo da unificação? E qual a garantia de menor custo e de maior eficiência do aparato policial depois da criação de uma polícia unificada, promovendo o ciclo completo? E como se dará o casamento das mentalidades oriundas das diferentes corporações? Qual a garantia de que não haverá taxas de atrito entre os diferentes segmentos da polícia unificada? Haverá uma "civilização" dos policiais militares ou uma "militarização" dos policiais civis? Diz-se que uma polícia de natureza civil será mais democrática e próxima da população, distante de procedimentos bélicos, da truculência e da letalidade que implicam elevados índices de violência contra os segmentos mais discriminados da sociedade. Será que uma polícia "civilizada", depois colocada no policiamento ostensivo, será realmente menos letal e truculenta? É verdade que a unificação das polícias deverá resultar em unidade doutrinária, mas essa unidade doutrinária será estadual ou nacional? De que centro emanaria essa unidade doutrinária? Uma mesma corporação civil realmente teria unidade doutrinária para as diferentes atribuições de cada segmento seu? A doutrina 
para as atividades investigativas é a mesma para as atividades de policiamento ostensivo? A doutrina para o policiamento ostensivo é a mesma para as operações de contenção de distúrbios?

Essa problematização básica, classificando as possíveis respostas a interesses de determinadas instituições em relação a outras, sugere particularização de cunho ético, tendente a não suportar a malha do interesse comum, geral ou público, que caracteriza a habitação "moral". Assim, não há pacificação pública por instrumentos regulamentares de auditagem ou assessoria técnica específica. No atinente parecer, Rocha (2014, p.31), rechaça ainda várias outras questiúnculas, tais como a parcimônia financeira decorrente de atividades burocráticas e solenidades, emprego do efetivo em outras instituições com o remanejamento adequado ao serviço operacional e promoção do ciclo completo de polícia, agregando-se a investigação (polícia judiciária), a exemplo da França, Itália, Portugal e Espanha. Neste diapasão, ainda, questiona Rocha (2014, p.31):

Quem garante que a extinção das Polícias Militares irá melhorar a segurança pública? Quem garante que a unificação das polícias irá diminuir as condutas desajustadas e, até mesmo, criminosas dos integrantes das corporações policiais? Como será uma polícia ostensiva sem o rigor da hierarquia e disciplina militares? Como será a letalidade dessa nova polícia diante dos mesmos desafios que hoje se impõem às Polícias Militares?

Percebe-se na narrativa de Rocha (2014) o conflito e defesa do modelo atual, com afloração de receio à possibilidade de inovação. As carreiras, tanto da polícia civil quanto das IME's são duplas, uma de cargos de execução técnica operacional e outra de Gestão. Esses números cargos podem ser racionalizados e sedimentados. Na atual conjuntura, a Unificação de ambas já recepcionam a paridade pelo número de cargos, nas respectivas carreiras. Mas a fusão em carreira única, racionalizará consideravelmente os cargos de gestão, como no arquétipo anglo-saxônico, Tais medidas podem ser mitigadas e pacificadas em cooperáveis regras de transição e oxigenação com concursos internos, por carreira única, com requisitos específicos às atividades de Gestão demandadas.

\section{PROBLEMAS QUE MOTIVAM A DESMILITARIZAÇÃO E A UNIFICAÇÃO}

Os fatores de fomento à reformulação da segurança pública são pluralizados. A realidade atual ostenta resultados estatísticos nefastos. Ademais a própria troca de Governo (MAIA et. al., 2018) e a indicação do novo Ministro da Justiça (SERGIO..., 2018), marcam amostras de eventos de crimes de 
elevados potenciais ofensivos que descrevem o cenário político, jurídico e social do Brasil. Assim, o clamor público legitimado no democrático processo eleitoral, inspira a quebra de paradigma sistêmica, abrangendo, desde o processo legislativo, até o sistema prisional. Vislumbra-se a possibilidade de mudanças racionais, a partir da dialética hegeliana de confronto dos opostos, à leitura de Ferreira (2013, p. 174-178), ao movimento helicoidal ascendente de tese, antítese e síntese, ou mesmo dialética da "racionalidade comunicativa" de Habermas (1990, 1991, 1992, 2002, 2003).

Considerando o paralelo norte-americano, com reformulação patriótica adotada contra corrupção até mesmo nos próprios órgãos de polícia, emergiu-se o slogan da política criminal "tolerância zero", em nova lorque, conforme diligências de Carlos (2016, p. 46, 47), com remessa aos estudos encetados por Wilson e Kelling (1982), além da teoria da janela quebrada, ou broken Windows. A título de ilustração, o experimento da pesquisa foi um veículo com vidros quebrados em bairros de níveis sociais diferentes, contudo com a mesma resposta, sugerindo-se que "[...] propriedades sem dono e bens móveis e imóveis com marcas de degradação são uma chamada para vândalos e até mesmo indivíduos ordeiros, todos fascinados pelo abandono.", depreendendo então que "[...] o crime e a desordem estão conexos, não permanecendo estima pela propriedade, já que bens em desordem simulam abandono, gerando as primeiras ações para a violência e o vandalismo.

Nesse diapasão, segundo Carlos (2016, p. 48) em resumo aos estudos de Bezerra (2008), com referência aos estudos de Kelling, George e Catherine Coles, do ano de 1996, a relação de causalidade entre a criminalidade violenta e a ausência de penalidade das pequenas contravenções e crimes, assim como a desordem incentivam a criminalidade, assim como a tolerância com pequenos delitos e contravenções leva à criminalidade violenta. Nesta ótica, os cidadãos têm suas condutas reguladas por penalidades, como explicita Salvador Netto (2008, p.205), que não colimam a injustiça, mas, sim, a retribuição, ou castigo correspondente mal praticado, e, a prevenção geral, desestimulando a todos, pela exteriorização da punição exemplar, para que não venham a delinquir, e, a prevenção especial, aplicando-se a punição adequada ao infrator, em prol de sua reabilitação.

Em tese de dissertação pertinente, Guedes (2016, p. 2-20), com fulcro nos postulados de Skogan (1993, 1999), Furstenberg (1971) Boers (2003), Gabriel e Greve (2003) e Rader (2004), o sentimento de insegurança (na terminologia anglo-saxónica fear of crime), aflora-se em três dimensões. A primeira, no medo do crime, pelo aspecto emocional, a segunda à percepção cognitiva do risco de vitimação, e a terceira, repercutida nas atitudes e comportamentos empreendidas pelo sujeito para garantias de segurança. Ou, ainda, numa medida expansiva, o sentimento de insegurança 
pode eclodir também em quatro vertentes, sendo três de natureza cognitiva, quais sejam, a preocupação das pessoas acerca da evolução e seriedade do crime e sua repercussão social, as avaliações de risco de vitimação (sentimento estrito de insegurança) e a ameaça percebida na situação do crime (potencialidade imaginária do dano a ser causado pelo delito). Na proposição de Skogan (1993, 1999), o nível de sensação do medo pode ser emergido na resposta à questiúncula: "quão seguro se sentiria a andar sozinho à noite?". A quarta tem caráter comportamental, operacional preventivo ou reativo.

Os estudos aguçam a existência de insatisfação social com os resultados auferidos pelos órgãos de segurança pública, em sentido amplo. Ou seja, por meio de ações questionáveis aos padrões de ética e moralidade. Sintetizando a questão, Vasconcelos e Gomes (2014, p.12) concluem pela racionalidade e necessidade da aprovação da PEC 51 (BRASIL, 2013), extinguindo o militarismo, patrocinando o ciclo completo de polícia, dentre várias outras vantagens. Entretanto, a PEC incentiva a legalização de várias instituições policiais, inclusive municipais, contrariando a uniformidade de tratamento a todas as pessoas em circunscrição nacional, além de dificultar o controle e fiscalização dos serviços. O modelo americano não contempla de pleno o federalismo Brasileiro (BARACHO JÚNOR, 2013; MORAES, 2013), gerando o excesso burocrático.

Em geral, as propostas de desmilitarização e unificação das polícias, ao escudo do trabalho de Rocha (2014), vislumbram a busca de uma substituição do modelo francês, incutido no Brasil desde o Império Real, para o paradigma anglo-saxônico (paramilitar). O modelo originário ocupa a maioria dos países colonizados pela França e outros europeus, a exemplo de Portugal, Espanha e Itália. Várias implicações administrativas e estruturais podem ocorrer, dentre elas destacou Rocha (2014, p.14, 35):

[...] proposta de emenda à Constituição, cujo trâmite é mais complexo e exige discussão e votação com dois turnos em cada Casa do Congresso Nacional (Senado Federal e Câmara dos Deputados), ou seja, quatro turnos ao todo, com o voto favorável, em cada turno, de $3 / 5$ dos seus membros, isto é, de 308 dos 513 deputados e 49 dos 81senadores.

[...]

É bem possível vislumbrar o que acontecerá quando as amarras da hierarquia e disciplinas forem soltas. Estará criado o maior sindicato armado do País, sujeito a todo tipo de contaminação sindicalista, ideológica e político-partidária e de interesses corporativos.

Cumpre observar que, conforme a tabela ou quadro comparativo da hierarquia das IME's do Brasil e dos EUA, o modelo estadunidense, almejado pelos defensores da desmilitarização e unificação das polícias e corpos de bombeiros, não expurga a hierarquia e disciplina, que está presente, inclusive na Polícia Civil, conforme acentuou Mendonça e Dantas (2016). Conforme preconiza Di Pietro 
(2014, p. 71, a hierarquia é intrínseca à Administração Pública, in verbis: "Em consonância com o princípio da hierarquia, os órgãos da Administração Pública são estruturados de tal forma que se cria uma relação de coordenação e subordinação entre uns e outros, cada qual com atribuições definidas na lei.". Numa ampliação analógica de carreira única, haveria uma redução significativa, desconsiderando-se o período dos cursos de formações, de 12 para 8 (oito) níveis hierárquicos, conforme cotejo com o Decreto-Lei n. 667 (BRASIL, 1969). Assim, numa carreira única com, com ingresso com nível superior (até a conclusão do curso de formação na corporação, para fins de nomeação) e concursos internos com requisitos especiais, de acordo com as funções (ex. Gestores da atividade-fim, Bacharel em Direito e pós graduação), sintetiza-se:

SIMBIOSE SIMULATIVA DAS IME'S NO MODELO DOS EUA

\begin{tabular}{|l|l|l|l|}
\hline \multicolumn{3}{|c|}{ FUSAO DAS IME'S E POLÍCIAS CIVIS (PARAMILITAR) } \\
\hline Ord & Cargo & $\begin{array}{l}\text { Divisa } \\
\text { ou } \\
\text { insígnia }\end{array}$ & Função \\
\hline 1 & $\begin{array}{l}\text { Coronel, } \\
\text { Superintendente, } \\
\text { Chefe }\end{array}$ & $\begin{array}{l}\text { Chefia de órgão autônomo ou } \\
\text { superior (Diretor, Cmt ou Chefe) }\end{array}$ \\
\hline 2 & $\begin{array}{l}\text { Tenente Coronel ou } \\
\text { Chefe Substituto }\end{array}$ & $\begin{array}{l}\text { Comandante Batalhão ou chefe } \\
\text { de Seccional. }\end{array}$ \\
\hline 3 & $\begin{array}{l}\text { Major ou Inspetor } \\
\text { Capitãonte }\end{array}$ & $\begin{array}{l}\text { Comandante de Companhia } \\
\text { Independente ou chefe distrital }\end{array}$ \\
\hline 5 & Tenente & $\begin{array}{l}\text { Comandante de Companhia ou } \\
\text { Chefe de Delegacia }\end{array}$ \\
\hline 6 & Sargento & $\begin{array}{l}\text { Chefe de Investigação } \\
\text { Fecruta }\end{array}$ & $\begin{array}{l}\text { Cmt de Guarnição ou equipe de } \\
\text { investigação }\end{array}$ \\
\hline 7 & Detetive & Noldado ou Policial & Investigador \\
\hline 8 & Recruta Formado & Patrulheiros \\
\hline
\end{tabular}

Conforme ostentado nas diligências de Mendonça e Dantas (2016), de forma independente ao modelo francês das "Gendarmarias", representando as polícias militares do mundo contemporâneo, o paradigma paramilitar anglo-saxônico avançou, por meio de Robert Peel, quando, em 1829, na Inglaterra, criou a Polícia Metropolitana de Londres, conhecida como a Scotland Yard.

Nos Estados Unidos, a extensão do modelo Inglês, consoante Mendonça e Dantas (2016), surgiu em 1838, com a fundação da "[...] primeira polícia moderna norte-americana na cidade de Boston em Massachusetts, seguida pela da cidade de Nova lorque em 1845 e de Albany, ambas no 
estado de Nova Iorque, e Chicago em Illinois, em 1851.", até então prevalecia a "polícia informal", denominadas de "constables ou constabulários", perpetuando, assim, mesmo depois da Revolução Americada de 1776.

Ainda, segundo Mendonça e Dantas (2016), progressivamente, em 1880 o modelo de policiamento fardado já era absoluto nas grandes cidades estadunidenses, todavia, no lapso do final do século XIX e início do século XX, estas polícias passaram por uma grave crise de confiança, em face às interferências políticas, comprometendo a eficiência de suas prestações estatais, pelos índices internos de corrupção e violência. Diante da instabilidade, em busca de solução, os Estados Unidos da América - EUA, paralelo à crise, patrocinaram estudos e mudanças, refletindo à unificação, à descrição de Mendonça e Dantas (2016):

Em meados do século XIX, o modelo policial sofreu uma intensificação da unificação dos vários departamentos de polícia localizados nas grandes cidades americanas, municípios e condados, facilitando enormemente o trabalho policial, pois diminuíram os problemas entre corporações, os custos da polícia e aumentou a eficiência. A unificação marca o nascimento da polícia moderna nos Estados Unidos da América.

A proposição revolucionária da modernidade dos EUA, segundo Mendonça e Dantas (2016), instituiu às novas polícias unificadas, com o fito da manutenção da ordem pública, de assegurar o cumprimento da lei e de servir a população, patrocinando na atualidade elevados índices de confiabilidade, inclusive citados como modelo referência a ser implantado no País.

O Estado Brasileiro, conforme narrativas de Borba (2016), Gamarski (2016) e Garcia (2016) destacam, na atualidade, exacerbada crise política e econômica e suas consequências para o povo, bem como o clima de descrédito e insegurança. A crise, que assola o mundo, de acordo com a temática "Assuntos económicos e financeiros" da Comissão Européia (ASSUNTOS..., 2016), reflete, no País, em baixa de produção, arrecadação, desemprego, endividamento e inclusive na instabilidade salarial aos funcionários públicos, a exemplo dos servidores do Rio de Janeiro, à luz de Satriano (2016), Corrêa e Oliveira (2016) e à notícia da Agência Minas (EM..., 2016), com previsão percepção mensal parcelada aos servidores mineiros. O IPEA (2016) associa o cenário fático de crises econômicas e políticas ao aumento da criminalidade, exemplificando com números constrangedores de taxas de homicídio em 2014, que tem acompanhado os dois últimos mandatos de governo, por conseguinte suplicando a racionalização administrativa.

Referendando ainda a conjuntura, o IPEA (2015, p. 96-111) em pesquisa para o Conselho Nacional de Justiça, descreve relatório com índices alarmantes de reincidência criminal, 
especialmente, de crimes contra o patrimônio e tráfico de entorpecentes. A situação súplica, conforme o atinente relatório (2015, p. 98) reforma da legislação penal, à recuperação presidiária e adequação da finalidade da pena (SALVADOR NETTO, 2008, p.205).

Com a evolução científica pós-moderna, mormente na esfera da tecnologia da informação, à demanda da segurança pública, preservação da ordem e preservação da incolumidade das pessoas e seus bens, o clamor público pela desmilitarização, dialeticamente, associa-se a ineficiência destes órgãos pelos elevados índices de criminalidade, além de onerosos dispêndios e gastos públicos, além da repercussão da crise política e econômica do País e do Mundo.

Vinculado à premissa da ineficiência, uma das questões suscitadas nos debates refere-se ao despreparo do policial, seja no trato com as pessoas, clientela constitucional, ou mesmo pela situação de risco em que as pessoas são submetidas às trocas de tiros e outras rivalidades de conflitos armados, conforme divulgação de policiais mortos em tiroteios, conforme reportagem de Valdevino (2016), descrevendo o elevado número de policiais mortos no Rio de Janeiro, e, à mesma linha de pensamento, Piza e Tomaz (2016), em relação a policiais de São Paulo.

Em senda similar, envolvendo mortes de civis por profissionais de segurança pública, à axiologia ponderativa dos princípios de Alexy (2005), alvora-se reflexões à premissa de que o crime deve ser coibido e não coagido. Um exemplo comum no Brasil decorre de ferimentos e mortes por balas perdidas em troca de tiros ou mesmo por iniciativa desses profissionais. Nestes casos, pressupõese que os gestores devem envidar treinamentos e acompanhamentos aos policiais da atividade-fim, com vistas a mensuração das medidas estratégicas menos traumáticas no combate aos fatores de insegurança social.

Numa mera formulação socrática, verbi gratia, sabido que o homem necessita fisiologicamente de dormir, alimentar-se, dentre outros, à vista da pirâmide de Maslow (MATEUS, 2013 , p. 31), ou mesmo que os veículos de transporte necessitam de combustível, estabilidade mecânica e outros, vislumbra-se a possibilidade de perseguições discretas e seguras, plenamente exequíveis por motocicletas e outros meios inteligentes de telecomunicação ou teleguiados como drones, sem perseguições inoportunas que colocam em risco a vida e o patrimônio de pessoas inocentes. $O$ planejamento unificado permite e incentiva ações estratégicas minimizando riscos e maximizando a eficiência no combate aos illícitos, ad exemplus, penais, de transito e ambientais.

A ilustração de fatos concretos ocorridos no período de janeiro a junho de 2016, noticiados pela imprensa, fazem-se elucidativos ao sugerido desiquilíbrio, quando de situações de mortes ou lesões de civis em perseguições que poderiam ter sido evitadas naquele momento e ambiente, mas oportunamente, considerando o raciocínio lógico, às características fisiológicas, de 
endereço certo, de fenômenos mecânicos de veículos empregados, dentre outros, insofismavelmente, vários eventos mortais poderiam ter sido evitados. . Faz-se questionável o fato daquele que tem a competência e a responsabilidade para "exalar" a sensação de segurança, proceder de forma adversa, conforme casos concretos e resultados objetivos. Depreende-se que, mesmo o profissional tendo sido treinado e habilitado para um palco de perigo de vida, não há justificativa axiológica plausível para transformar uma mera infração administrativa, em concurso de ilicitos penais, transformar um ambiente pacífico em cenário de troca de tiros, projéteis perdidos, mortes e danos diversos.

Exemplificando faticamente a assertiva, somente no ano de 2016, mesmo diante de debates constantes, à luz da ponderação dos valores em conflito (ALEXY, 2005), já ocorreram vários eventos teratológicos, tais como: 1) em 14 de janeiro, no sul do País, conforme divulga Abati (2016): "Engenheiro foi morto por tiro da BM após fugir de abordagem, diz polícia"; 2) Araújo (2016) narra fato de que, em 14 de março: "Jovem fura blitz, colide contra poste e capota o carro na Roberto Freire[...]". Em vários editoriais foram perceptivos eventos similares consecutivos, no decurso de 2016, dentre os quais, com maior afinidade contextual, destacam-se: 3) em 17 de maio, em Salvador (JOVEM..., 2016): "Jovem é baleado após tentar fugir de blitz na Avenida Bonocô, [...]"; 4) em 10 de junho, no Rio de Janeiro (PSICÓLOGA..., 2016): “Psicóloga é baleada na cabeça ao tentar fugir de falsa blitz no Rio"; 5) em 14 de junho, no Recife (UM..., 2016): “Um jovem morre e dois ficam feridos depois de furar bloqueio da PM"; 6) conforme divulgado pelo editorial do Tribuna Online (MOTORISTA, 2016), em 27 de junho, mais um episódio trágico ocorrido em Vítória, no Espírito Santo “O motorista de um Corolla prata ultrapassou o bloqueio de uma blitz e atropelou um policial do Batalhão de Polícia de Trânsito (BPTran), na noite desse domingo [ ]".

Outro caso concreto análogo decorre de um vídeo do YouTube (TVC..., 2016), descrevendo uma perseguição e troca de tiro com menor em fuga, em veículo furtado, que comparado com um caso recente (DOIS , 2018), demonstra uma rotina de ineficiência e sem inovações pelos gestores da segurança pública. Diante de pressuposto de menor ou adulto armado, além das reflexões acima descritas, no que couber: 1) o que gerou os disparos pelo menor, tem ou não relação com a percepção ou consciência de estar sendo perseguido? 2) os disparos ofereceram risco aos transeuntes? 3) existe conceito estratégico de "perseguição segura" ou similar nas respectivas instituições policiais? Esses policiais foram orientados, em banco de escola ou pela coordenação da central 190, acerca dos fatores axiológicos periféricos como condicionantes da ação e seus efeitos? Dentre outros quesitos.

Nessa conjuntura situacional, verifica-se que a atividade de segurança pública, seja pelo modelo francês ou anglo-saxão, por serem intrínsecas à abordagem humana, para garantia, restrição ou imposição de direitos e responsabilidades, além da oferta universitária hodierna e princípio da 
eficiência, reclama o prestígio da exigência de nível superior para ingresso nas fileiras institucionais. Ademais, o peculiar exercício do poder de polícia (DI PIETRO, 2014, p. 123), como expressão da força coercitiva ou repressiva do Estado, de acordo com o caso concreto, mesmo para a atividade primária de execução, pela sua complexidade jurídica e nuanças das atividades ainda da polícia judiciária, exige, por razoabilidade, a formação superior, como requisito sine qua non a título de recrutamento e seleção, como acontece na Polícia Civil Mineira, ao manto da combinação dos arts. 76 e 83 da Lei complementar n. 129 (MINAS GERAIS, 2013), e, Polícia Militar de Minas Gerais, com fulcro nos arts, 5o, inc. V, 6ㅇ, 6-A e 6--B, da Lei n 5.301 (MINAS GERAIS, 1969), bem como o bacharelado em Direito para as atividades de gestão inerentes às atribuições de polícia judiciária dos delegados e dos oficiais de carreira da Polícia Militar.

O treinamento de automatização, destreza e objetivação metodológica de incursões em situações de risco é essencial, mas há também exigência de raciocínio lógico e holístico para atuação no cenário real de operações, pois, os fatores periféricos ponderativos a serem observados são pluralizados e complexos. Neste sentido, o discurso dialético, peculiar ao pensamento reflexivo universitário, depreende-se, promove várias teses axiológicas à melhor atuação e eficiência da prestação estatal da segurança pública.

Em plano exemplificativo, considerando a amostragem jornalística alhures, alguns questionamentos primários, inerentes à filosofia dos cursos de graduação, pelo crivo dos bens jurídicos envolvidos e categorizados, promoveriam incógnitas salutares, tais como: 1) na situação de fuga, em bloqueio de trânsito, se a atividade de ilícito administrativo não alcança o nível de potencial ofensivo criminal, por que a perseguição e os disparos em via pública? 2) O que recebe maior valoração, a vida humana, a insegurança das pessoas ou as multas e medidas administrativas cabíveis ao proprietário infrator? 3) Quem deveria minimizar e manter a segurança das pessoas, nesses casos o fizeram? 4) As ações adotadas inibiram ou aumentaram os riscos? 5) O sistema de informação do Detran do respectivo Estado está bloqueado à consulta dos policiais em operação? 6) O combustível do veículo infrator, em caso de perseguição segura, era perene? 7) Houve contatos, por telefone ou tecnologias disponíveis, com o proprietário ou família vinculada ao veículo em fuga? E outros.

Ora, como discorrido no tópico das guardas e agentes de trânsito municipais, já existe no mercado tecnologia de hardware e software para emissão de todas as informações automaticamente, identificando veículo e pessoas, inclusive mapeando deslocamentos em via pública diuturnamente, a exemplo dos GPS (PHILIPE, 2014), comuns aos celulares, inclusive para aplicação das sanções instantaneamente ou oportunamente, a exemplo da implantação de CHIP passivo ou ativo nos veículos automotores e pontos marcadores nas vias terrestres (BELING, 2017). Todavia, o controle e vigilância 
eletrônica devem observar os limites, verbi gratia, da Lei Federal 12.527 (BRASIL, 2011), em relação à privacidade das pessoas, até mesmo no processamento do mapeamento dos fluxos e deslocamentos dos veículos em via pública. São procedimentos exequíveis, com dados e diagnósticos (imediatos e reais), potencializando a redução sobremaneira os esforços humanos com o policiamento ostensivo, de furtos de veículos ou mercadorias de considerável valor econômico, dentre outros, além de ser promissora à arrecadação em prol da sustentabilidade do sistema de segurança pública. Em breve simulação, com um sistema de leitura de CHIP ou código de barras (passivo), ou a ausência evidenciada (à ilustração de um veículo furtado ou clandestino em via pública), canalizaria à imediata identificação probatória de ilícito penal, cível ou administrativo. Por conseguinte, no caso ilustrativo em tela, fomenta-se o planejamento eficiente e oportuno para a captura ou apreensão suplicada pela matéria (seja por meio de aproximação ou perseguição velada ou mesmo instalação de acessório eletrônico marcador ou espião à efetivação das diligências, dentre outros). O sistema de monitoramento eletrônico demandado, a exemplo do fluxo automotivo de determinada avenida de repercussão das cidades capitais, por exemplo, pode sugerir desde rotas alternativas, álibis e soluções de conforto, inclusive mapeando as demandas periódicas localizadas da segurança pública.

\section{REFLEXOS DA DESVINCULAÇÃO DO CBM DA PM E DA PERÍCIA DA PC}

A segregação da segurança pública implica compartimentação de responsabilidade, prejudicando não só a sociedade, mas também as categorias de profissionais vinculadas, em geral, atendendo-se a inchaços na pluralização de cúpula, a sedimentação de casas éticas (privatizações de poder e concorrência entre as referidas instituições) em detrimento da habitação moral (interesse público sem distinção de pessoas, ou casas éticas). Ou seja, uma casa dividida para formar outras, multiplicando-se as cadeiras, por exemplo de um Secretário de Estado de segurança pública para três ou quatro (Comandante-Geral da Polícia Militar, Comandante-Geral do CBM, Chefe da Polícia Civil, Chefe do Instituto de Criminologia (Perícia Técnica) e Chefe dos Agentes Penitenciários. Por conseguinte haverá a multiplicação uniforme de seus gerentes e das demandas administrativas, além de remanejamentos do efetivo de execução operacional para a atividade-meio, desguarnecendo a atividade-fim, e, assim, reclamando ampliação de vagas e concursos públicos afins (sistema perverso, análogo ao câncer que destrói, por meio do inciso $V$ - cargos comissionados, todo o caput do art. 37 da CRFB, BRASIL, 1988). 
Desta feita, onera-se sobremaneira o Estado pelos gastos públicos e amplia-se ainda a possibilidade de conflitos de interesses (pessoalidade), a exemplo do nível de autonomia e discricionariedade dos atos (em cotejo com o desvio e excesso de poder), como alude Di Pietro (2014, p. 251, 252), mormente em face dos gerentes, nesse caso multiplicados, quando a base do efetivo de execução permanece a mesma, sendo parte dela remanejada para a nova Administração (criada, emancipada), enquanto investimentos de mesmo calibre econômico em tecnologia da informação, hardwares e softwares, poderia racionalizar e solucionar com maior exatidão as demandas de gestão existentes (BANCO..., 2008).

Outro fator relevante é a concorrência ética entre os órgãos estatais, e respectivas leniências e "soluções de continuidade", a exemplo, na própria seara da segurança pública, na perseverante quebra e frustrações do "ciclo completo de polícia" (a exemplos dos atos encetados pela Polícia Militar e atos sucessivos da Polícia Judiciária ou investigativa). Há ainda a concorrência extravagante de órgãos municipais e até mesmo da União e dos Estados-membros, como vislumbrado na questão da segurança pública de trânsito, arbitrariamente executada pelas guardas municipais, DNIT, DER. Nas atividades BM, há ainda a invasão de Bombeiros Civis e voluntários, dentre outros. Nas atividades da segurança pública ambiental, os próprios órgãos administrativos ambientais, como no exemplo da mineradora SanMarco, em Minas Gerais, dedutivamente aprovando projetos típicos de segurança pública, sem a confirmação das IME's (FERRACIOLI e SBARANI, 2016, p. 1).

Numa grata analogia, conforme comparou Oliveira (2017, p. 113), à colossal evangelização de Pulo de Tarso, os órgãos, cada qual com sua função, todos essenciais devem operar em harmonia na integralização do "ente". Assim, quaisquer disfunções podem acusar tumores, transformando o "ente" em figura teratológica. Portanto, a sinergia, o respeito, a fluência comunicativa e dinamismo mútuo entre os órgãos são primordiais à higidez e eficiência do "ente". Entretanto, a multiplicação de órgãos para ampliar cargos de gestão e reduzir ainda mais o oneroso efetivo operacional implica "obesidade" e inibição da destreza suplicada pela expectativa da prestação da força física do Estadomembro, comprometendo a segurança pública e a economia do ente. Assim preconizou o apóstolo (BÍBLIA SAGRADA, 1 Co, 12):

19. E, se todos fossem um só membro, onde estaria o corpo? 20. Assim, pois, há muitos membros, mas um corpo. 21. E o olho não pode dizer à mão: Não tenho necessidade de ti; nem ainda a cabeça aos pés: Não tenho necessidade de vós. 22. Antes, os membros do corpo que parecem ser os mais fracos são necessários; 23. E os que reputamos serem menos honrosos no corpo, a esses honramos muito mais; e aos que em nós são menos decorosos damos muito mais honra. 24. Porque os que em nós são mais nobres não têm necessidade disso, mas Deus assim formou o corpo, dando muito mais honra ao que tinha falta dela; 25. Para que não haja divisão no corpo, mas antes tenham os membros igual cuidado uns 
dos outros. 26.De maneira que, se um membro padece, todos os membros padecem com ele; e, se um membro é honrado, todos os membros se regozijam com ele.

Outro considerável conflito interno são os holofotes éticos das respectivas instituições (HABERMAS, 2003, p. 129) ${ }^{12}$, quando algumas já estão constitucionalmente sedimentadas no lastro da "carreira jurídica", enquanto outras desassociam, mas continuam empregando esforços técnicos distantes da finalidade eleita, comprometendo a eficiência e objetivamente vulgarizando o know-how da missão constitucional. Neste sentido, reitera-se, para ingresso na carreira primária de gerentes da polícia civil (Delgado de Polícia), o candidato deve ter como requisito fundamental a graduação em Direito. A Polícia Militar, a exemplo de Minas Gerais, também passou a exigir o bacharelado em Direito, considerando o acervo do exercício de polícia judiciária e as atividades de direitos humanos (com demandas de conhecimento em direito penal, processual, administrativo, ambiental, trânsito e outras demandas).

Nesse contexto, a exemplo do CBMMG, contrariando o seguimento da PM, a norma não exige o curso de Direito para o oficialato, mas continua praticando os atos de polícia judiciária, quando quem é habilitado para fazê-lo é a PC e a PM, além de compor com exclusividade o escabinato de bombeiros militares (autônomo em relação à PMMG) O art. 125, § 4으, da CRFB (BRASIL, 1988), preconiza que: “Compete à Justiça Militar estadual processar e julgar os policiais militares e bombeiros militares nos crimes militares definidos em lei e as ações judiciais contra atos disciplinares militares, [...].". Laconicamente, nesses casos, caso haja cometimento de crime militar praticado por bombeiro militar, a feitura do inquérito pelo CBM (desconstituído de habilitação técnica - exigência da formação em direito para ingresso) representa objetivamente a vulgarização da atividade de polícia judiciária, potencialmente colimando vícios de pessoalidade, injustiça e indução aos representantes do Ministério Público, que confia na fé pública do Estado.

Pela lupa da malha ética, à simetria de equacionamento implica, no mínimo, a formação do conselho permanente composto proporcionalmente por praças, em consonância à reflexão de Rosa (2002). Numa comparação mais ampla, conforme disponibilizado pelo Ministério da Defesa (BRASIL, 2017), o efetivo total da Marinha, Exército e Aeronáutica, com base em decretos regulamentadores de 2012 e 2013, somam 47. 962 oficiais (e 396.852 praças), portanto o universo seletivo (sorteio) para composição dos respectivos conselhos são proporcionalmente legitimados.

\footnotetext{
${ }^{12}$ A partir de então, aquilo que desde os tempos de Aristóteles era conhecido como "ética", recebe um novo sentido subjetivista. Isso vale tanto para histórias de vidas individuais como para tradições e formas de vidas compartilhadas intersubjetivamente.
} 
Dessarte, portanto, tecnicamente, a opção do CBMMG, quando da sua emancipação, por distanciar da carreira jurídica, contra o norte Constitucional, gerou ônus que desassiste a corporação no exercício da investigação criminal militar de seus integrantes. Nesta senda, o inquérito penal militar é cabível ao órgão das IME's, constitucional e tecnicamente habilitado por rígido processo seletivo (escolha dos melhores bacharéis em direito inscritos no certame - diferentemente do que possa ocorrer no CBMMG, em relação a bombeiros que venham a se formar de forma adjacente, no decurso da carreira, pois não podem ser afirmados como habilitado se não foram aprovados pelo crivo específico), qual seja, a polícia judiciária da PMMG. A Polícia Civil realiza as investigações criminais nos crimes comuns.

Além disso, a Policia Militar, a exemplo de Minas Gerais, ao exigir o curso de bacharel em Direito no concurso à carreira do oficialato, também mitiga e suporta questionamentos acerca da legitimidade (HABERMAS, 2003, p. 133) ${ }^{13}$ à composição do "escabinato" (conselho de oficiais militares para julgar militares - CABRAL e KUBIK, 2011, p.131) nas respectivas auditorias de justiça militar. Esta composição jurisdicional, à égide de habermasiana se enquadra como uma composição de casta ética, cabível em matéria e penalidades administrativas exaradas por conselhos profissionais (como a OAB no julgamento da conduta de determinado advogado, do CREA em relação ao Engenheiro, do CRM no tocante ao médico e assim sucessivamente).

A alçada "moral ${ }^{14 ", ~ c o m p o r t a ~ a ~ p r e s t a c ̧ a ̃ o ~ j u r i s d i c i o n a l, ~ c o m ~ p e n a l i d a d e s ~ d e c o r r e n t e s ~ d e ~}$ “norma nacional" - não federal ou federativa, conforme Oliveira $\left(2017\right.$, p. 80) ${ }^{15}$, com fulcro em Barros (2014). O escabinato busca analogia à composição do tribunal do júri, formado por representantes do povo, para julgar os do povo por crime de homicídio (ARAÚJO, 2008, p. 91-105), mas há divergência quanto à legitimidade e finalidade, em que PMMG, ad exemplus, inova, saneando os atinentes

\footnotetext{
${ }^{13}$ Argumentos em prol da legitimidade do direito devem ser compatíveis com os princípios morais da justiça e da solidariedade universal - sob pena de dissonâncias cognitivas - bem como com os princípios éticos de uma conduta de vida auto-responsável, projetada conscientemente, tanto de indivíduos, como de coletividades.

${ }^{14}$ Num caso se examina se uma máxima é boa para mim ou adequada à situação; no outro caso, se posso querer que uma máxima seja observada como lei universal para todos. (Habermas: 1992, p.294)

${ }^{15}$ Por prisma de categorização do alcance circunscricional normativo, aditiva Barros $(2014$, p. 62,63$)$ a subdivisão teleológica das normas (leis) em federal, federativa e nacional. A primeira limita-se à circunscrição de origem, do respectivo ente federativo, sendo intransitiva aos demais entes federativos, a exemplo da Lei n. 9.784 (BRASIL, 1999), aplicável aos servidores públicos federais, a Lei n. 14.184 (MINAS GERAIS, 2002), embora com teor de réplica da lei federal, aplicável apenas aos servidores do Estado mineiro.

A lei federativa tem repercussão transitiva, com aplicação procedimental a todos os entes da Administração Pública, a exemplo das disposições predominantes da Lei Complementar n. 140 (BRASIL, 2011a) e da Lei n. 8.666 (BRASIL, 1993), e a lei nacional, expressando ordenação a todos, em condições de igualdade, em todos os rincões da federação, a exemplo da Lei n. 9.605 (BRASIL, 1998) e do Decreto-Lei n. 2.848 (BRASIL, 1940).
} 
conceitos habermasianos $(1992, \text { p.299 })^{16}$. Neste contexto, a PM confirma o escabinato com o saber jurídico, composto por oficiais bacharéis em Direito (art. 142, § $3^{\circ}$, da CE (MINAS GERAIS, 1989, ipsis verbis: "Para o ingresso no Quadro de Oficiais da Polícia Militar - QO-PM - é exigido o título de bacharel em Direito e a aprovação em concurso público de provas ou de provas e títulos, realizado com a participação da Ordem dos Advogados do Brasil, [...]." - Grifou-se), selecionados em rígido concurso público. Entretanto, o CBMMG, além de não constituir efetivo mínimo para composição exclusiva por oficiais da corporação (efetivo mínimo de 20 mil militares - §§3으 e 5으, do art. 125, da CRFB, BRASIL, 1988$)^{17}$, seus oficiais não são da mesma "forja" da PMMG. Neste diapasão, pelo crivo técnico do burilado conhecimento jurídico, os oficiais do CBMMG não têm legitimidade para composição do escabinato, quiçá exclusiva de bombeiros militares, e sequer para realizar inquéritos policiais militares, cabendo então à PMMG, suprir as lacunas.

A modernidade dos princípios constitucionais norteadores da prestação jurisdicional eficiente, econômica e célere, como imperam o art. 5ำ, em diversos incisos (especialmente: LXXVIII - a todos, no âmbito judicial e administrativo, são assegurados a razoável duração do processo e os meios que garantam a celeridade de sua tramitação.), seu $§ 20$ (que aduz: Os direitos e garantias expressos nesta Constituição não excluem outros decorrentes do regime e dos princípios por ela adotados, ou dos tratados internacionais em que a República Federativa do Brasil seja parte.), e, caput do art. 37, "[...] legalidade, impessoalidade, moralidade, publicidade e eficiência e, [...]:", da CRFB (BRASIL, 1988). Assim, a inteligência constitucional, mesmo na perpetuação das instituições avulsas, conforme o acréscimo de competência à justiça militar estadual, é a prevalência do juízo singular em primeira instância e o colegiado ad quem.

${ }^{16} \mathrm{O}$ discurso prático-moral representa a ampliação ideal de nossa comunidade de comunicação a partir da perspectiva interior. Diante desse fórum, só podem encontrar assentimento fundamentado aquelas sugestões de norma que expressam um interesse comum de todos os envolvidos. Nesta medida as normas fundamentadas discursivamente fazem valer a um só tempo duas coisas: o conhecimento daquilo que a cada momento reside no interesse geral de todos, e também uma vontade geral que apreendeu em si sem repressão a vontade de todos. Neste sentido, a vontade determinada por fundamentos morais não permanece exterior à razão argumentativa; a vontade autônoma é completamente interiorizada na razão.

${ }^{17}$ Art. 125. Omissis.

$[\ldots]$.

$\S$ 3으 A lei estadual poderá criar, mediante proposta do Tribunal de Justiça, a Justiça Militar estadual, constituída, em primeiro grau, pelos juízes de direito e pelos Conselhos de Justiça e, em segundo grau, pelo próprio Tribunal de Justiça, ou por Tribunal de Justiça Militar nos Estados em que o efetivo militar seja superior a vinte mil integrantes.

[...].

§ 5o Compete aos juízes de direito do juízo militar processar e julgar, singularmente, os crimes militares cometidos contra civis e as ações judiciais contra atos disciplinares militares, cabendo ao Conselho de Justiça, sob a presidência de juiz de direito, processar e julgar os demais crimes militares. 
A partir do momento em que a PM se consolida como carreira jurídica, ampliando a qualificação e eficiência da prestação estatal, em sinergia com a Polícia Civil, e de outro modo a linha do CBM e do Instituto de criminalística, afastam-se também da paridade de subsídios ou vencimentos de seus servidores. Portanto, a autonomia também repercute em ônus e responsabilidade objetiva.

Um exemplo clássico dessa cisão e ônus decorrentes está positivada no art. 46 da Constituição paranaense (PARANÁ, 1989), que, atividade-fim da segurança pública, cria a Polícia Científica, que era uma atividade-meio da Polícia Civil, assim como os carcereiros e agentes penitenciários. Os Estados-membro não estão autorizados a criar órgãos diversos ou além dos previstos no art. 144 da CRFB (BRASIL, 1988). Não se pode atribuir à Polícia Científica, ou mesmo aos Agentes Penitenciários, atribuições-fim da preservação da ordem ou preservação da incolumidade pública das pessoas e do patrimônio, senão subsidiárias ou tácitas. Este é objetivamente mais um ônus da ruptura, divisão ou emancipação institucional. $\mathrm{O}$ art. 46 da aludida Constituição Estadual (PARANÁ, 1989), preconiza:

Art. 46. A Segurança Pública, [...], pelos seguintes órgãos:

I - Polícia Civil;

II - Polícia Militar;

III - Polícia Científica.

Parágrafo único: O Corpo de Bombeiros é integrante da Polícia Militar.

A desvinculação ou segregação das instituições de segurança pública reverbera efeitos jurídicos diversos das medidas políticas empreendidas. Paliativamente multiplicam-se os cargos de gerentes, empreendimentos logísticos e financeiros significativos, além de remanejamento dos servidores operacionais da atividade-fim, para atividade-meio. Ademais, subsume-se, a cisão implica guinadas éticas em detrimento do interesse público ou bem comum de todos (habitação moral), ofuscando a lisura teleológica da segurança pública. A persecução técnica da carreira jurídica é axiologicamente consentânea à demanda temática, enquanto a direção em outros ramos implica desnivelamento, inclusive, salarial. Nesse diapasão, o CBM não congrega habilitação técnica em paridade com a PM para o exercício das atribuições de polícia judiciária e até mesmo para composição dos respectivos conselhos.

\section{REFLEXOS E ADAPTAÇÕES NECESSÁRIAS A DESMILITARIZAÇÃO E UNIFICAÇÃO COM A POLÍCIA} CIVIL 
As IME's, na atualidade, no tocante às normas pátrias de caracterização da uniformidade e reconhecimento formal como instituição militar (Decreto-lei n. 667, BRASIL, 1969; Lei n. 5.821, BRASIL, 1972; Lei n. 6.880, BRASIL, 1980), carecem de ríspida supervisão do Exército Brasileiro, em especial no tocante aos processos promocionais das atinentes carreiras e estruturas administrativas e operacionais, à prestação laborativa de isenção e de busca da excelência profissional. As Legislações estatuais de regulação das matérias em causa, não podem destoar, sob pena de "descredenciamento material e formal como instituição militar".

Em caso de desmilitarização e unificação das IME's à PC, vislumbram-se transições essenciais e compatíveis às pretendidas reformas previdenciárias, além da adequação e uniformidade dos servidores de segurança em serviço ativo e na eminência da aposentadoria. Outrossim, os servidores já aposentados tem o Direito de rever e opinar pela categorização correspondentes dos subsídios, além de escolha e perpetuação do instituto de previdência oficial eleito. Esta definição do instituto previdenciário é essencial, em virtude dos direitos adquiridos dos aposentados filiados, mas cabendo estudos conjuntos entre as instituições afetas, ao corolário do princípio da compensação.

O Estado deve envidar estudos acerca da definição da carreira única, prestigiando o conhecimento e o tirocínio agregado a cada patamar alcançado, mediante concurso interno, a partir do terceiro patamar. O processo promocional atual, a exemplo das IME's do Estado de Minas Gerais é dispendioso e contém arbítrios e subjetividade não comportado pelo paradigma do regulamento promocional das Forças Armadas, provocando o princípio da hierarquia e disciplina, por conseguinte injustiça, protecionismo ou perseguição. A partir de uma instituição paramilitar, de acordo com os cargos e funções, prima facie, o mais isento seria concurso interno de provas e título, definindo-se requisitos específicos, à cada um dos, no máximo, 7 (sete) patamares sucessivos, considerando que o primeiro decorre de concurso público (mas prevendo também a promoção por antiguidade (para que o servidor alcance pelo menos quatro níveis no decurso da carreira, por antiguidade). Para os servidores da ativa e aposentados, com busca na paridade, caberia estudos de transição, compatibilizando-se os níveis alcançados e mais próximos dos postos ou graduações alcançados e aproximação positiva do cargo mais próximo, para a definição do "subsídio" compatível. Considerando o número exacerbado de gerentes atuais, cabe também estudos de transição, e diluição até a extinção dos referidos cargos.

A fusão desses órgãos é promissora, especialmente na racionalização dos órgãos maiores e médios, liberando efetivo para o serviço operacional e reduzindo cargos e funções (a serem amortizados na regra de transição), mormente por considerar o relevância da tecnologia no controle e processamento automático de dados, dentre outros. 
Para efetivação da quebra de paradigma, não basta assunção de responsabilidade pela União, Estados-membros e Distrito Federal, por intermédio dos órgãos da Segurança Pública e de controle externo, mas, assim o referendar em legislação própria, em especial alterando a redação do art. 144, da CRFB (BRASIL, 1988), que pode avocar a responsabilidade à União ou manter a reverberação programática aos Estados-membros e Distrito Federal. É inadmissível e obsoleto, na atualidade, o modelo "gendarmaria" no País, consoante a demonstração concreta das ocorrências policiais trágicas em evidência no Brasil (a exemplo de interrupção da circulação de um veículo para exigir documentos afins ou mesmo informações de procedência, sabido que estes dados estão todos catalogados e disponibilizados, pelo respectivo Departamento Estadual de Trânsito, aos agentes de trânsito, por via das centrais de atendimento “190"). Em breve ilustração, até por senso comum, ad exemplus, determinado veículo em fuga de uma determinada blitz (se já existem as demandas de veículos com exacerbado número de multas, que podem ser categorizadas pela gravidade da ofensa, valor do veículo, ou ainda na situação de queixa ou denúncia de furto), todos esses automóveis com proprietários e fatos identificáveis formalmente, com descrição, em tese, de endereços certos, para exercício tempestivo do poder de polícia (DI PIETRO, 2014, P. 123), pode sofre intervenções e medidas administrativas cabíveis de modo planejado e oportuno (seja em caráter preventivo ou reativo), sem ampliar ou gerar risco de vida e danos a pessoas envolvidas ou não no evento.

Numa perscrutação de exequibilidade à capacidade de resposta tecnológica atual, a "perseguição ou abordagem segura", ou seja, sem despertar a "consciência, receio e medo" no infrator, que possam the causar reações de riscos potenciais, podem implicar maior tempo de dedicação do servidor em determinada ocorrência, entretanto, à linha weberiana (GODOI, 2008; PETRY, 2004; WEBER, 2004; OLIVEIRA, 2013; OLIVEIRA, 2017), o sistema foi feito para o homem e não o contrário. Estes eventos, inclusive com a possibilidade de filmagem (com câmaras eficientes de satisfatória capacidade resolutiva e de zoom), com imagens que poderiam ser transmitidas ao vivo a plantões estratégicos, que, monitorando, repassariam as medidas a serem adotadas pela guarnição ou equipe de vigilância, perseguição ou abordagem, solidariamente, desencadeando, de forma oportuna e segura a abordagem.

Quanto a estrutura da Justiça Militar Estadual, não se vislumbra prejuízo, pois os juízes a quo são concursados e podem incorporar e somar às respectivas jurisdições estaduais, ou mesmo habilitar uma vara especializadas para julgar servidores de segurança pública, em composição singular. Concernente ao colendo colegiado ad quem, poderá integrar Câmara específica do respectivo Tribunal de Justiça do Estado, considerando a legalidade e legitimidade da ocupação dos alusivos Cargos. 
No tocante à logística inerente, vislumbra-se que a vigilância eletrônica monitorada nas vias públicas são mais econômicas, permitindo-se registros audiovisuais essenciais à formação de provas e planejamentos preventivos e reativos oportunos. O Estado deve rever conceitos acerca do excesso burocrático inerentes à aquisição de bens e serviços, bem como a vida útil, consumo, deterioração, e custo-benefício dos procedimentos e processos licitatórios, vez que, politicamente, ad exemplus, muitas construtoras capazes e idôneas são inabilitadas por requisitos capciosos que contemplam determinadas empresas, aumentando sobremaneira as estimativas financeiras (portanto, essas variáveis devem ser revistas).

\section{CONSIDERAÇÕES FINAIS}

A Segurança Pública, dever do Estado, direito fundamental individual e coletivo, portanto, responsabilidade de todos, insculpida nos baluartes da preservação da ordem e incolumidade públicas, reflete por afinidade material ao interesse difuso, cabendo procedimentos e medidas uniformes, regulado por normas de caráter nacional, típicos da expressão e chancela da soberania republicana.

Apesar da baliza constitucional federal e dos respectivos Estados, especialmente nas áreas limítrofes territoriais de cada Estado, havendo clamor, as IME's mais próximas devem atuar em prol da Segurança Pública. Axiológicamente, melhor que haja superposição de esforços por erro ou extrapolação da circunscrição, do que, da mesma forma, por ruído de comunicação ou excesso de zelo ao limite territorial, deixar de ser prestada a segurança suplicada.

A moderna tecnologia cogitada, à inteligência weberiana, já está disponível e acessível no mercado, permitindo mapeamento, alarmes sutis e potencialmente inibindo todas as ações análogas de risco. Existem celulares, sistemas de CHIP que identificam, monitoram e mapeiam automaticamente veículos e peças, armamento, presos, estudantes e até mesmo o cidadão de bem, restando ao Estado a chancela da definição de escopos e inusitada e pioneira implantação de conforto às atividades de segurança pública.

Independente do seguimento das IME's e Polícia Civil, à complexidade das tarefas de execução da segurança pública, ao prestígio da sociedade, disponibilidade seletiva satisfatória, exequível, conveniente, razoável e oportuna a exigência uniforme de candidatos com nível de escolaridade superior para ingresso no quadro inicial e a graduação em Direito para os cargos de gestão, nessas instituições. Para fins de ascensão na carreira, o processo promocional das Forças Armadas são os mais isentos e consonantes ao princípios da hierarquia e disciplina, entretanto, para 
fins de inovação, verifica-se que o incentivo à especialização pode permitir uma carreira mínima de quatro níveis por antiguidade e a partir do terceiro nível a opção de promoção por merecimento, por provas e títulos, com critérios exclusivamente objetivos. É inadmissível, na atualidade, que o maior nível hierárquico dessas instituições não possuam, pelo menos, uma pós-graduação stricto sensu em Direito ou Ciências sociais.

Nessa lupa, o Estado oferece e regulamenta as oportunidades de ascensão na carreira, cabe aos interessados, no que couber, o preenchimento tempestivo, pelos meios próprios e sem prejuízo do serviço, dos requisitos estipulados à promoção. O conhecimento é a mola mestra propulsora às criações, soluções de conflitos e eficiência da missão constitucional. Assim, também o curso de formação de ingresso ao primeiro cargo, apesar da exigência de curso superior, podem ser dilatados, cabendo a este público, escalas extras em eventos especiais, onde serão avaliados diuturnamente, até a conclusão do curso. O profissional desqualificado técnico ou cientificamente, desinteressado e descompromissado com os valores institucionais, são alijados pelas empresas privadas, quanto mais à plausividade do serviço público.

As premissas em elação visam a eficiência da segurança pública, a proteção e à estabilidade financeira estatal, o combate à criminalidade e a corrupção, além de especial zelo aos respectivos institutos previdenciários, cabendo estudos à conveniência e oportunidade de ampliação do tempo de aposentadoria, especialmente dos gestores (vez que o perfil profissiográfico e o escopo da capacidade laborativa afeta às respectivas atribuições não vinculam necessariamente o vigor e destreza física inerente do efetivo operacional), bem como redução de cargos gerenciais. No militarismo estadual não justifica tantas seções, unidades e cargos para as mesmas atividades, como os departamentos de pessoal ou de recursos humanos.

O Estado não pode ser refém de erros ou especulações e oscilações estatísticas de financeiro. Assim, há necessidade de extinção de penduricalhos de folha de pagamento e definição de subsídios específicos à categorização hierárquica dos cargos, conforme expresso na CRFB (BRASIL, 1988), com transição de nivelamento, inclusive dos aposentados e pensionistas, segundo os títulos dos cargos correspondentes alcançados na inatividade.

Diante das construções lapidadas, em face dos resultados dialéticos das crises emergentes, eventos de corrupção, instabilidade econômica, necessidade de racionalização administrativa, depreende-se, por viável a desmilitarização e unificação das Instituições estaduais de segurança pública, sedimentando-se uma carreira única, com redução do número de cargos e unidades gestoras, à simetria do arquétipo paramilitar estadunidense. 
Essas alternativas implicam breves alterações nos arts. 42, 125, 142 e 144 da CRFB, com reverberações às constituições estaduais e normas programáticas afetas, sem inibir o apoio necessário dos órgãos de segurança pública às Forças Armadas, em caso de guerra.

O interesse local não pode prevalecer sobre o interesse nacional da segurança pública, portanto, o município (quanto mais seus órgãos internos), ou ainda outros órgãos estaduais (a exemplo do DER) ou da própria União (a exemplo do DNIT), não são competentes para o exercício estratégico, técnico e de elevada complexidade jurídica, de quaisquer dos órgãos típicos de segurança pública.

\section{REFERÊNCIAS}

ABATI, Lucas. Engenheiro foi morto por tiro da BM após fugir de abordagem, diz polícia. Gaucha Clicrbs, Porto Alegre, 14 jan. 2016. Disponível em: <http://gaucha.clicrbs.com.br/rs/noticiaaberta/engenheiro-foi-morto-por-tiro-da-bm-apos-furar-blitz-diz-policia-156532.html>. Acesso em: 10 jul. 2016.

AGOSTINHO, Santo. O livre-arbítrio. 2. ed. São Paulo: Paulus, 1995.

ALBUQUERQUE, Afonso de. Um outro "Quarto Poder": imprensa e compromisso político no Brasil. Contracampo, Rio de Janeiro, 2002. Disponível em: <http://www.contracampo.uff.br/index.php/revista/article/view/414/201>. Acesso em: 12 nov. 2016.

ALEXY, Robert. Teoria da argumentação jurídica. 2. ed. São Paulo: Landy, 2005.

ALEXY, Robert. Teoria dos direitos fundamentais. Tradução de Virgílio Afonso da Silva. 2. ed. São Paulo: Malheiros Editores, impresso no Brasil, 2011.

AQUINO, Tomás de. Suma teológica: São Paulo: Edições Loyola, 2004, v. V.

AQUINO, Tomás de. Suma teológica: São Paulo: Edições Loyola, 2005, v. IV, v. VI.

ARAÚJO, Flávia Simões. Júri clássico e escabinato: estatísticas da adoção de ambos os sistemas de julgamento na atualidade. 2008. 129 f. Dissertação (Mestrado em Direito) - Centro Universitário de Toledo, Araçatuba, 2008. Disponível em:

<http://www.dominiopublico.gov.br/download/teste/arqs/cp075329.pdf>. Acesso em: 25 maio 2016.

ARAÚJO, Rafael. Jovem fura blitz, colide contra poste e capota o carro na Roberto Freire Jornal Nominuto, Natal, 14 mar. 2016. Disponível em: <http://www.nominuto.com/noticias/policia/jovemfura-blitz-colide-contra-poste-e-capota-o-carro-na-roberto-freire/138157/>. Acesso em: 31 jul. 2016.

ARISTÓTELES. Ética nicomáquea. Madrid: Gredos, 1998. 
ASSUNTOS económicos e financeiros: perspectivas econômicas europeias. Comissão Europeia. 3 maio 2016. Disponível em:

<http://ec.europa.eu/economy_finance/explained/economies_of_europe/european_economic_outl ook/index_pt.htm>. Acesso em: 23 jun. 2016.

ATARAXIA. Artigos de apoio Infopédia [filosofia]. Porto Editora, Porto, 2003. Disponível em: <https://www.infopedia.pt/apoio/artigos/\$ataraxia-(filosofia)>. Acesso em: 22 out. 2016.

BANCO Mundial aprova financiamento de US\$ 7 bi ao Brasil. Uol Notícias, São Paulo, 1 maio 2008. Disponível em: <https://noticias.uol.com.br/ultnot/efe/2008/05/01/ult1808u118095.jhtm>. Acesso em: 26 jul. 2017.

BARACHO JÚNIOR, José Alfredo de Oliveira. Intervenção Federal e Intervenção Estadual no Estado Federal. In: RAMOS, Dircêo Torrecillas. O Federalista Atual: Teoria do Federalismo. Belo Horizonte: Arraes, 2013, p.93-107.

BARROS, Sérgio Resende de. Lei Federal, Lei Federativa, Lei Nacional. In: RAMOS, Dircêo Torrecillas. O Federalista Atual: Teoria do Federalismo. Belo Horizonte: Arraes, 2013, p.60-66.

BELING, Fernanda. IBM anuncia chip com tecnologia de 5 nanômetros: A IBM juntou a tecnologia EUV e o processo de fabricação GAAFET e conseguiu um chip de 5 nanômetros. Seu ganho de desempenho é $40 \%$ maior se comparado com um chip de 10 nanômetros e seu consumo de energia é 75\% menor. Oficina da Net, Santa Cruz do Sul, 6jun. 2017. Disponível em: $<$ https://www.oficinadanet.com.br/post/19230-ibm-anuncia-chip-com-tecnologia-de-5nanometros>. Acesso em: 10 set. 2018.

BEZERRA, Jorge Luiz. Segurança pública, uma perspectiva político criminal à luz da teoria das janelas quebradas. São Paulo: Blucher Acadêmico, 2008.

BíBLIA SAGRADA. N. T. 1 Coríntios. Tradução de Almeida, corrigida e fiel, 1994. Cap. 12. Disponível em <http://www.bibliaonline.com.br/> Acesso em: 05 jun.2008.

BOERS, K. (2003). Fear of violent crime. In Heitmeyer, W., e Hagan, J. (Eds.), International Handbook of Violence Research (pp. 1131-1150). Dordrecht: Kluwer Academic Publishers.

BONAVIDES, Paulo. Curso de direito constitucional. 26. ed. São Paulo: Malheiros, 2010.

BORBA, André. A profunda crise política e econômica e suas consequências para o povo: analistas, filósofos e juristas destacam clima de descrédito, insegurança e de radicalização. Jornal do Brasil, Rio de Janeiro, 11 jun. 2016. Disponível em: <http://www.jb.com.br/pais/noticias/2016/06/11/aprofunda-crise-politica-e-economica-e-suas-consequencias-para-o-povo/>. Acesso em: 29 jun.2016.

BRASIL. Ministério da Defesa. Efetivo. Brasília, 2017. Disponível em: $<$ https://www.defesa.gov.br/anistia/111-lei-de-acesso-a-informacao/perguntasfrequentes/remuneracao-dos-militares-das-forcas-armadas-no-brasil-e-no-exterior/8637-efetivos>. Acesso em: 20 out. 2018; 
BRASIL. Ministério da Justiça. Secretaria de Segurança Pública. Estudo profissiográfico e mapeamento de competências: perfil dos cargos das instituições estaduais de segurança pública. Brasília, 2012. Disponível em: <https://www.mpma.mp.br/arquivos/CAOPCEAP/Profissiografia.pdf> . Acesso em: 20 dez. 2018

BRASIL. Presidência da República. Constituição (1824). Constituição Política do Império do Brasil, 1824. Disponível em: <http://www.planalto.gov.br/ccivil_03/Constituicao/Constituicao24.htm>. Acesso em: 2 maio 2016.

BRASIL. Presidência da República. Constituição (1891). Constituição da República dos Estados Unidos do Brasil, 1891. Disponível em:

<http://www.planalto.gov.br/ccivil_03/Constituicao/Constituicao91.htm>. Acesso em: 2 maio 2016.

BRASIL. Presidência da República. Constituição (1934). Constituição da República dos Estados Unidos do Brasil, 1934. Disponível em:

<http://www.planalto.gov.br/ccivil_03/Constituicao/Constituicao34.htm>. Acesso em: 2 maio 2016.

BRASIL. Presidência da República. Constituição (1937). Constituição dos Estados Unidos do Brasil, 1937. Disponível em:<http://www.planalto.gov.br/ccivil_03/Constituicao/Constituicao37.htm>. Acesso em: 2 maio 2016.

BRASIL. Presidência da República. Constituição (1946). Constituição dos Estados Unidos do Brasil, 1946. Disponível em:<http://www.planalto.gov.br/ccivil_03/Constituicao/Constituicao46.htm>. Acesso em: 2 maio 2016.

BRASIL. Presidência da República. Constituição (1967). Constituição da República Federativa do Brasil, 1967. Disponível em:

<http://www.planalto.gov.br/ccivil_03/Constituicao/Constituicao67.htm>. Acesso em: 2 maio 2016.

BRASIL. Presidência da República. Constituição da República Federativa do Brasil, de 5 de outubro de 1988. Disponível em: <http://www.planalto.gov.br/ccivil_03/Constituicao/Constituicao.htm>. Acesso em: 2 nov. 2018.

BRASIL. Presidência da República. Decreto-Lei n. 667, de 2 de julho de 1969. Reorganiza as Polícias Militares e os Corpos de Bombeiros Militares dos Estados, dos Território e do Distrito Federal, e dá outras providências. Diário Oficial da União, Brasília, 3 jul. 1969c. Disponível em: <www.planalto.gov.br/ccivil_03/decreto-lei/Del0667.htm>. Acesso em: 2 maio 2016.

BRASIL. Presidência da República. Decreto n. 7.308, de 22 de setembro de 2010. Altera o Decreto no 6.944, de 21 de agosto de 2009, no tocante à realização de avaliações psicológicas em concurso público. Diário Oficial da União, Brasília, 23 set. 2010. Disponível em:

<https://www.planalto.gov.br/ccivil_03/_ato2007-2010/2010/decreto/d7308.htm>. Acesso em: 20 nov.2016.

BRASIL. Presidência da República. Emenda n. 1, de 17 de outubro de 1969. Edita o novo texto da Constituição Federal de 24 de janeiro de 1967. Disponível em:

<http://www.planalto.gov.br/ccivil_03/Constituicao/Emendas/Emc_anterior1988/emc01-69.htm>. Acesso em: 19 mai. 2016. 
BRASIL. Presidência da República. Lei n. 5.821, de 10 de novembro de 1972. Dispõe sobre as promoções dos oficiais da ativa das Forças Armadas e dá outras providências. Diário Oficial da União, Brasília, 10 nov. 1972. Disponível em><http://www.planalto.gov.br/ccivil_03/LEIS/L5821.htm>. Acesso em: 20 jul. 2016.

BRASI. Presidência da República. Lei n. 6.880, de 9 de dezembro de 1980. Dispõe sobre o Estatuto dos Militares. Diário Oficial da União, Brasília, 11 dez. 1980. Disponível em: <http://www.planalto.gov.br/ccivil_03/LEIS/L6880.htm>. Acesso em: 20 ago. 2018.

BRASIL. Presidência da República. Lei n. 9.503, 23 de setembro de 1997. 1nstitui o Código de Trânsito Brasileiro. Diário Oficial da União, Brasília, 24 set. 1997. Disponível em:

<http://www.planalto.gov.br/ccivil_03/leis/L9503.htm>. Acesso em: 21 jun. 2016.

BRASIL. Senado Federal. Proposta de Emenda à Constituição $n^{\circ}$ 51, de 2013: Altera os arts. 21, 24 e 144 da Constituição; acrescenta os arts. 143-A, 144-A e 144-B, reestrutura o modelo de segurança pública a partir da desmilitarização do modelo policial. Brasília, 12 set. 2017. Disponível em: <https://www25.senado.leg.br/web/atividade/materias/-/materia/114516>. Acesso em 07 jul. 2018.

BRASIL. Superior Tribunal de Justiça. Ações que discutem competência do DNIT para aplicar multas de trânsito estão suspensas em todo o país. STJ Notícias: Brasília, 17 out.2016. Disponível em: $<$ http://www.stj.jus.br/sites/STJ/default/pt_BR/Comunica\%C3\%A7\%C3\%A3o/noticias/<Not \%C3\%ADcias/A\%C3\%A7\%C3\%B5es-que-discutem-compet\%C3\%AAncia-do-DNIT-paraaplicar-multasde-tr\%C3\%A2nsito-est\%C3\%A3o-suspensas-em-todo-o-pa\%C3\%ADs>. Acesso em: 10 nov.2016

CABRAL, Rafael Lamera; KUBIK, Erika. A Justiça Militar no pós-1988: A Busca Pela Efetivação Democrática e a Defesa dos Direitos Humanos. Anais do Encontro Internacional de Direitos Humanos, v.1, n.1, p. 129-137 (2011). Disponível em: <http://anaisonline.uems.br/index.php/encontrointernacional/article/view/2550/2723>. Acesso em: 25.Jul.2016.

CAMPBELL, Donald J.; CAMPBELL, Kathleen M. Police/military convergence in the USA as organisational mimicry. Policing end Society, New York, 8 aug. 2014. Disponível em: <https://www.tandfonline.com/doi/full/10.1080/10439463.2014.942852>. Acesso em: 20 dez. 2017.

CANOTILHO, J. J. Gomes. Direito constitucional e teoria da Constituição. 7. ed. Coimbra: Almedina, 2003.

CARLOS, Mônica Perpétua. Meio ambiente urbano e sua influência para a prática de crime. Local: Belo Horizonte. Minas Gerais - Brasil. 2016. 88f. Dissertação (Mestrado em Direito Ambiental e Desenvolvimento Sustentável) - Escola Superior Dom Helder Câmara, Belo Horizonte, 2016. Disponível em: <http://domhelder.edu.br/mestrado/editor/assets/arquivos_dissertacoesdefendidas/b6394b63b6f8 7c9ffd64dab4dc94bcaf.pdf>. Acesso em 19 ago.2016.

CASSEB, Paulo Adib. O Sistema de Segurança Militar e Civil no Estado Federado - Estrutura - A Guarda Municipal. In: RAMOS, Dircêo Torrecillas. O Federalista Atual: Teoria do Federalismo. Belo Horizonte: Arraes, 2013, p.360-367. 
COSTA, Beatriz Souza; OLIVEIRA, Edson Rodrigues de. O patamar hierárquico da Resolução Conama: uma Análise pelos óculos da ação direta de inconstitucionalidade 3.074 e holofotes da soberania repúblicana e autonomia dos entes federativos. Revista Argumentum, (RA), Marília, v. 16, p. 209232, 2015. Disponível em: <http://ojs.unimar.br/index.php/revistaargumentum/article/view/155>. Acesso em: 20 mar. 2016.

CASTILHO, Ricardo. Estado: Elementos Constitutivos, Conceito, Objetivos e Tipos. In: RAMOS, Dircêo Torrecillas. O Federalista Atual: Teoria do Federalismo. Belo Horizonte: Arraes, 2013, p.2-34.

CORRÊA, Hudson; OLIVEIRA, Graziele. Caos nas contas do Rio de Janeiro trazem estado de calamidade e onda de crimes Revista Época, São Paulo, 17 jun.2016. Disponível em:

$<$ http://epoca.globo.com/tempo/noticia/2016/06/caos-nas-contas-do-rio-de-janeiro-trazem-estadode-calamidade-e-onda-de-crimes.html>. Acesso em: 22 jul. 2016.

CRETELLA JÚNIOR, José. Comentários à Constituição Brasileira de 1988. Rio de Janeiro: Forense Universitária, 1992, 581p. (v.1)

CUNHA, Antonio Geraldo da. Dicionário Etimológico Nova Fronteira da Língua Portuguesa. 2. Ed. Rio de Janeiro: Nova Fronteira, 1986, p. 711.

DIMOULIS, Dimitri; MARTINS, Leonardo. Teoria geral dos direitos fundamentais. 2. ed. São Paulo, 2009.

DI PIETRO, Maria Sylvia Zanella. Direito administrativo. 27. ed. São Paulo: Atlas, 2014.

DOIS menores são detidos após acidente com carro furtado no Ipiranga: Houve perseguição policial e motorista capotou o veículo no cruzamento das ruas Japurá e Coronel Américo Batista, zona Norte de Ribeirão Preto. A Cidade On, Ribeirão Preto, 3 out. 2018.Disponível em:

<https://www.acidadeon.com/ribeiraopreto/cotidiano/policia/NOT,0,0,1376987, dois+menores+sao+ detidos+apos+acidente+com+carro+furtado+no+ipiranga.aspx>. Acesso em: 3 nov. 2018.

EM estado de calamidade financeira, MG parcela 13 de servidores até março. Agência Brasil, Brasília, 8 dez. 2016. Disponível em: <http://agenciabrasil.ebc.com.br/economia/noticia/201612/em-estado-de-calamidade-financeira-mg-parcela-13o-de-servidores-ate-marco>. Acesso em: 20 fev. 2017.

FAIAD, Cristiane; COELHO JUNIOR, Francisco Antonio; CAETANO, Patrícia Fagundes; ALBUQUERQUE, Anelise Salazar. Análise Profissiográfica e Mapeamento de Competências nas Instituições de Segurança Pública. Psicologia: Ciência e Profissão, Brasília, vol.32, n.2, p. 388-403, 2012. Disponível em: < http://www.scielo.br/pdf/pcp/v32n2/v32n2a09.pdf>. Acesso em: 20 nov.2016.

FIGUEIREDO, Antônio Macena. 2008. Ética: origens e distinção da moral. Revista Saúde, Ética \& Justiça, v. 13, n. 1, 2008. Disponível em:

<http://www.revistas.usp.br/sej/article/view/44359/47980>. Acesso em: 18 out.2015.

FERRACIOLI, Paulo; SBARAINI, Giulia. Molduras de uma tragédia anunciada: enquadramentos do desastre de Mariana. In: CONGRESSO DE CIÊNCIAS DA COMUNICAÇÃO NA REGIÃO SUL, 17.

Universidade Federal do Paraná, Curitiba, 26-28 maio 2016. Anais..., Curitiba: Intercom, 2016. 
Disponível em: <http://www.portalintercom.org.br/anais/sul2016/resumos/R50-0837-1.pdf>. Acesso em: 20 jun. 2016.

FERREIRA, Fernando Guimarães. Dialética hegeliana: uma tentativa de compreensão. Rev. Estudos Legislativos, Porto Alegre, ano 7, n. 7, p. 167-184, 2013. Disponível em: <https://pt.scribd.com/document/351116689/Dialetica-de-hegel-pdf>. Acesso em: 10 out. 2017.

FURSTENBERG, F. (1971). Public reactions to crime in the streets. The American Scholar, 40(4), 601610.

GABRIEL, U.; GREVE, W. (2003). The psychology of fear of crime: conceptual and methodological Perspectives. British Journal of Criminology, 43(1), 600-614.

GAMARSKI, Rachel. CNI entrega a Temer lista com 36 medidas 'indispensáveis'. Estadão, São Paulo, 29 abr. 2016. Disponível em: <http://politica.estadao.com.br/noticias/geral,cni-entrega-a-temerlista-com-36-medidas-indispensaveis,10000047238>. Acesso em: 25 jul. 2016.

GARCIA, Giselle. Entenda a crise econômica. Agência Brasil, Brasília, 5 maio 2016. Disponível em: <http://agenciabrasil.ebc.com.br/economia/noticia/2016-05/entenda-crise-economica>. Acesso em: 22 jul. 2016.

GODOI, Rodrigo Tavares. A ciência da Kultur na obra de Max Weber. Revista Mosaico, Goiânia, v. 1, n. 1, p. 61-73, jan./jun., 2008. Disponível em:

<http://caminhos.ucg.br/index.php/mosaico/article/download/230/184>. Acesso em: 2 maio 2016.

GREENPEACE. Lama até o pescoço: Greenpeace chega às comunidades de Mariana, em Minas Gerais, para documentar a tragédia causada pelo rompimento das barragens da mineradora Samarco. [Vista do arraial de Bento Rodrigues (@Victor Moriyama/Greenpeace)]. Greenpeace Notícias, 15 nov.

2015. Disponível em: <http://www.greenpeace.org/brasil/pt/Noticias/Lama-ate-o-pescoco/>. Acesso em: 29 jul. 2016.

GUEDES, Inês Maria Ermida de Sousa. Medo do crime: emergência, reações emocionais e discursos contributos para a utilização de multi-metodologias. 2017. 412f. Tese (Doutorado em Criminologia) Faculdade de Direito da Universidade do Porto, Porto-PT, 2016. Disponível em:

$<$ https://www.researchgate.net/profile/Ines_Guedes3/publication/315613586_Medo_do_crime_em ergencia_reacoes_emocionais_e_discursos_Contributos_para_a_utilizacao_da_multi-

metodologias/links/58d55b95aca2727e5ea917e1/Medo-do-crime-emergencia-reacoes-emocionaise-discursos-Contributos-para-a-utilizacao-da-multi-metodologias.pdf>. Acesso em 25 jul. 2018.

HABERMAS, Jurgen. Agir comunicativo e razão destranscendentalizada. Rio de Janeiro: Tempo Brasileiro, 2002.

HABERMAS, Jurgen. Dialética e liberdade: para o uso pragmático, ético e moral da razão prática. Organização de E. Stein e L. A. de Boni. Tradução de Márcio Suzuki. Porto Alegre: Petrópolis, 1992.

HABERMAS, Jurgen. Direito e democracia: entre facticidade e validade. Tradução de Flávio Beno Siebeneichler (UGF). 2. ed. Rio de Janeiro: Tempo Brasileiro, 2003.

HABERMAS, Jurgen. Ética comunicativa y democracia. Barcelona: Critias, 1991. 
HABERMAS, Jurgen. Pensamento pós-metafísico: guinada pragmática. Rio de Janeiro: Tempo Brasileiro, 1990, p. 65-125.

HERRERO,f. Javier. A Pragmática Transcendental como Filosofia Primeira. Síntese Nova Fase, Belo Horizonte, v.24, n.79, p. 497-512, 1997.

INSTITUTO DE PESQUISA ECONÔMICA APLICADA (IPEA). Taxa de homicídios no Brasil atingiu recorde em 2014: país tem o maior número absoluto de homicídios no mundo. 2016. Disponível em: $<$ http://www.ipea.gov.br/portal/index.php?option=com_content\&view=article\&id=27412>. Acesso em: 10 ago. 2016.

JOVEM é baleado após tentar fugir de blitz em Salvador. Bahianoar, Salvador, 17 maio 2016. Disponível em: <https://bahianoar.com/jovem-e-baleado-apos-tentar-fugir-de-blitz-em-salvador/>. Acesso em: $20 \mathrm{dez}$. 2017B

KANT, Immanuel. A metafísica dos costumes: a doutrina do Direito e a doutrina da virtude. São Paulo: EDIPRO, 2003.

KANT, Immanuel. Fundamentação da metafísica dos costumes. Lisboa: Edições 70, 1988.

LIMA, Igor Frederico Fontes de; OLIVEIRA, Ilzver de Matos. Segurança Pública Militarizada: A Face Antidemocrática do Estado de Direito. Revista Interfaces Científicas - Direito, Aracaju, v. 4, n. 2, p. 93-102, fev. 2016. Disponível em: <https://periodicos.set.edu.br/index.php/direito/article/viewFile/3016/1623 >. Acesso em: 2 maio 2016.

MAIA, Gustavo; Luciana Amaral, PRAZERES, Leandro; GARCIA, Janaina. Bolsonaro leva facada em ato de campanha em Juiz de Fora (MG). UOL, em Brasília e em São Paulo, 06 set. 2018. Disponível em: <https://noticias.uol.com.br/politica/eleicoes/2018/noticias/2018/09/06/bolsonaro-em-juiz-defora.htm?cmpid=copiaecola>. Acesso em: 20 out. 2018.

MAINGUENEAU, Domenique. Termos-chave da análise do discurso. Tradução de Márcio Venício Barbosa. Belo Horizonte: UFMG. 2000.

MATEUS, Fátima de Nazaré Melo Brito. Motivação no trabalho: um estudo de caso na gestão administrativa do hospital Divina Providência. 2013. 115 f. Dissertação (Mestrado em Gestão) Escola de Ciências Económicas e das Organizações, Universidade Lusófona de Humanidades e Tecnologias. Lisboa, 2013. Disponível em: <http://recil.grupolusofona.pt/bitstream/handle/10437/4678/DISSERTA\%C3\%87\%C3\%830 \%20F\%C3\%81TIMA\%20MATEUS.pdf?sequence=1>. Acesso em: 29 nov. 2015.

MEGALE, Maria Helena Damasceno e Silva. A compreensão virtuosa do direito: reflexão sobre a ética na hermenêutica jurídica. Revista Brasileira de Estudos Políticos, Belo Horizonte, v. 97, p. 71-104, 2008. Disponível em: <http://www.pos.direito.ufmg.br/rbepdocs/097071104.pdf>. Acesso em: 10 jul.2016.

MEIRELLES, Hely Lopes. Direito Administrativo Brasileiro. 29. Ed. São Paulo: Malheiros, 2004. 
MENDONÇA, Olavo Freitas; DANTAS, George Felipe Lima. Um estudo de polícia comparada: Brasil e Estados Unidos da América. Distrito Federal: Sindicato dos Policiais Federais no Distrito Federal, 2016. Disponível em: <http://www.fenapef.org.br/um-estudo-de-policia-comparada-brasil-eestados-unidos-da-america/>. Acesso em: 5 maio 2016.

MINAS GERAIS. Constituição do Estado de Minas Gerais de 1989. Disponível em: <http://www.almg.gov.br/consulte/legislacao>. Acesso em 27 de junho de 2015.

MINAS GERAIS. Assembleia Legislativa do Estado de Minas Gerais. Lei n. 5.301, de 16 de outubro de 1969. Contém o Estatuto dos Militares do Estado de Minas Gerais [texto atualizado]. Diário do Executivo, Belo Horizonte, 18 out. 1969a, ratificada no Diário do Executivo, Belo Horizonte, 6 dez. 1969. Disponível em:

<http://www.ipsm.mg.gov.br/arquivos/legislacoes/legislacao/leis/LEl_5.301.pdf>. Acesso em: 22 fev. 2016.

MORAES, Alexandre. Direito constitucional. 30. ed. São Paulo: Atlas, 2014.

MORAES, Guilherme Peña de. Tipos de Estado Federal. In: RAMOS, Dircêo Torrecillas. O Federalista Atual: Teoria do Federalismo. Belo Horizonte: Arraes, 2013, p.108-120.

MOTA, Leda Pereira; SPITZCOVSKY, Celso. Curso de Direito Constitucional. 6. ed. São Paulo: Editora Juarez de Oliveira, 2001.

MOTORISTA fura blitz e atropela policial. TribunaOnline, Vitória, 27 jun. 2016. Disponível em: < https://tribunaonline.com.br/motorista-fura-blitz-e-atropela-policial >. Acesso em 20 dez. 2017.

OLIVEIRA, Edson Rodrigues. A competência constitucional do Corpo de Bombeiros Militar para atuação na proteção ambiental. 2017. 176f. Dissertação (Mestrado em Direito) Escola Superior Dom Helder Câmara, Belo Horizonte, 2017b. Disponível em: $<$ http://domhelder.edu.br/mestrado/editor/assets/arquivos_dissertacoesdefendidas/8 90a58fa5dbb6d35e38619b40dd232c8.pdf>. Acesso em: 4 maio 2017.

OLIVEIRA, Márcio Luís de. A Constituição Juridicamente Adequada: Transformações do Constitucionalismo e Atualização Principiológica dos Direitos, Garantias e Deveres Fundamentais. Belo Horizonte: Arraes, 2013.

PARANÁ. Constituição do Estado do Paraná. Disponível em: < http://www.alep.pr.gov.br/system/files/corpo/constituic_parana.pdf $>$. Acesso em 27 de outubro de 2018.

PETRY, Almiro. Max Weber: o intelectual e o homem político. Revista Opinio, Canoas, n. 13, p. 7-18, 2. sem. 2004. Disponível em:

<http://www.ulbra.br/upload/8b4cf1df16ce1dfa917caaa753853ea0.pdf\#page=7>. Acesso em: 2 maio 2016.

PIMENTA, Marcelo Vicente de Alkimim. Teoria da Constituição. Belo Horizonte: Del Rey, 2007. 
PIZA, Paulo Toledo; TOMAZ, Kleber. Um PM morto a cada seis dias no primeiro bimestre de 2016 em SP. O Globo, São Paulo, 2016. Disponível em: <http://g1.globo.com/sao-paulo/noticia/2016/03/umpm-foi-morto-cada-seis-dias-no-primeiro-bimestre-de-2016-em-sp.html>. Acesso em: 28 maio 2016.

PHILIPE, Gabriel. Como funciona o GPS? O Sistema de Posicionamento Global, popularmente conhecido como GPS (Global Positioning System), utiliza satélites para detectar sua localização e mostrar exatamente onde você está. Oficina da Net, Santa Cruz do Sul, 21 fev. 2014. Disponível em: <https://www.oficinadanet.com.br/post/12406-como-funciona-o-gps>. Acesso em: 10 set. 2018.

PLATÃO. A república. 7. ed. Lisboa: Fundação Calouste Gulbenkian, 1993.

PLATÃO. Leyes. Diálogos. Madrid: Gredos, 1999.

PRATICAMENTE falidos, 5 estados atrasam pagamentos: Avidez do governo federal; estrutura arcaica, centralizadora, da federação; e incompetência gerencial cobram seu preço. Pátria Paulista, São Paulo, 21 dez. 2017. Disponível em: <https://patriapaulista.com/praticamente-falidos-5-estadosatrasam-pagamentos/>. Acesso em: 20 out. 2018.

PSICÓLOGA é baleada na cabeça ao tentar fugir de falsa blitz no Rio. Globo.com, Rio de Janeiro, 10 jun. 2016. Disponível em: <https://extra.globo.com/casos-de-policia/psicologa-baleada-na-cabecaao-tentar-fugir-de-falsa-blitz-no-rio-19469468.html >. Acesso em: 20 dez. 2017.

Rader, N. (2004). The threat of victimization: a theoretical reconceptualization of fear of crime. Sociological Spectrum: Mid-South Sociological Association, 24(6), 689-704.

RAMOS, Dircêo Torrecillas. O Federalista Atual: Teoria do Federalismo. Belo Horizonte: Arraes, 2013, p.84-92.

ROCHA, Cármen Lúcia Antunes. República e Federação no Brasil: Traços constitucionais da organização política brasileira. Belo Horizonte: Del Rey, 1997.

ROCHA, Claudionor. Segurança pública e seus enigmas. 2011. Disponível em: $<$ http://www2.camara.leg.br/documentos-e-pesquisa/públicacoes/estnottec/areasdaconle/tema21/2011_1380.pdf>. Acesso em: 2 maio 2016.

ROCHA, Fernando Antônio Nogueira Galvão. Tribunal do Júri na Justiça Militar. MPMG Jurídico, Belo Horizonte, v. 8, p. 68-71, 2007. Disponível em:

<https://www.mpmg.mp.br/lumis/portal/file/fileDownload.jsp?fileld=8A91CFA942729E9301 42991C72103685>. Acesso em: 20 jun. 2016.

ROCHA, Fernando Carlos Wanderley. Desmilitarização das Polícias Militares e Unificação de Polícias: desconstruindo mitos [Parecer]. Brasília: Câmara dos Deputados, Consultoria Legislativa, 2014, 45p. Disponível em: <http://www2.camara.leg.br/documentos-epesquisa/fiquePorDentro/temas/unificacao-de-policias/Texto\%20Consultoria.pdf >. Acesso em: 2.mai.2017. 
ROSA, Alexandre Reis; BRITO, Mozar José de. Corpo e alma nas organizações: um estudo sobre dominação e construção dos corpos na organização militar. RAC, Curitiba, v. 14, n. 2, p. 194-211, 2010. Disponível em: <www.anpad.org.br/rac>. Acesso em: 2 maio 2016.

SALVADOR NETTO, Alamiro Velludo. Finalidades da Pena, Conceito Material de Delito e Sistema Penal Integral. Tese (Doutorado em Direito Penal), Faculdade de Direito, Universidade de São Paulo, São Paulo/SP, 2008. Disponível em: <http://www.teses.usp.br/teses/disponiveis/2/2136/tde-17022009160214/pt-br.php>. Acesso em 14 de abril de 2015.

SATRIANO, Nicolás. Atraso de pagamento do Governo do RJ deixa servidores com nome 'sujo'. 0 Globo, Rio de Janeiro, 29 jun. 2016. Disponível em: <http://g1.globo.com/rio-dejaneiro/noticia/2016/06/atraso-de-pagamento-do-governo-do-rj-deixa-servidores-com-nomesujo.html >. Acesso em: 22 jul.2016.

SERGIO Moro aceita ser ministro de Jair Bolsonaro e não interrogará o ex-presidente Lula. Blasting News, Lugano [Suíça], 01 nov. 2018. Disponível em:

$<$ https://br.blastingnews.com/politica/2018/11/sergio-moro-aceita-ser-ministro-de-jair-bolsonaro-enao-interrogara-o-ex-presidente-lula-002762493.html>. Acesso em: 2 nov.2018.

SIGNIFICADOS. Significado de Estratégia: Estratégia é uma palavra com origem no termo grego strategia, que significa plano, método, manobras ou estratagemas usados para alcançar um objetivo ou resultado específico. 7Graus, Porto, 6 fev. 2017 [atualização]. Disponível em: <https://www.significados.com.br/estrategia/>. Ace3sso em: 8 jul. 2018.

SILVA, José Afonso da. Curso de direito constitucional positivo. 37. ed. São Paulo: Malheiros, 2013b.

SILVA, José Afonso da. Curso de Direito Constitucional Positivo. 19.ed. São Paulo: Malheiros, 2001, $684 / 878 p$

SILVA, Daniel Carvalho da. A felicidade segundo Sêneca. Revista Inquietude, Goiânia, v. 4, n. 1, p. 3143, 2013a. Disponível em: <http://www.inquietude.xanta.org/index.php/revista/article/view/163>. Acesso em: 22 jun. 2016.

SKOGAN, W. (1993). The various meanings of fear. In Bilsky, W., Pfeiffer, C., e Wetzels, P. (Eds.), Fear of crime and criminal victimization(pp. 131-140). Stuttgart: Enke.

SKOGAN, W. (1999). Measuring What Matters: Crime, Disorder and Fear. In Lanworthy, R. (Ed.), Measuring What Matters: Proceedings from the Policing Research Institute Meetings. Research Report. Washington, DC: U.S. Department of Justice, National Institute of Justice and Office of Community Oriented Policing Services.

TVC - Garoto de 10 anos morre após troca de tiros com Polícia. YouTube, condado de Santa Clara [Califórnia - EUA], 3 jun. 2016. Disponível em: <https://www.youtube.com/watch?v=1_utwHaJOLA>. Acesso em: 2 nov, 2018.

UM jovem morre e dois ficam feridos depois de furar bloqueio da PM Rapazes praticaram assaltos e fugiram de blitzes na Zona Norte do Recife: Segundo PM, foram encontrados arma de brinquedo, facão e celulares. Globo.com, Pernambuco, 14 jun. 2016, Disponível em: 
<http://g1.globo.com/pernambuco/noticia/2016/06/um-jovem-morre-e-dois-ficam-feridos-depoisde-furar-bloqueio-da-pm.html>. Acesso em: 20 dez. 2016.

VALDEVINO, Diego. Dezoito dos 41 policiais mortos este ano estavam na Baixada ou na Zona Oeste. O Dia, Rio de Janeiro, 23 maio 2016. Disponível em: <http://odia.ig.com.br/rio-de-janeiro/2016-0523/dezoito-dos-41-policiais-mortos-este-ano-estavam-na-baixada-ou-na-zona-oeste.html>. Acesso em: 23 maio 2016.

VASAK, Karel. As dimensões internacionais dos direitos do homem. Lisboa: Editora Portuguesa de Livros Técnicos e Científicos; Unesco, 1983.

VASAK, Karel. Revisiter la troisième génération des droits de l'homme avant leur codification. In: Héctor Gros Espiell amicorum liber: personne humaine et droit international. Bruxelles: Bruylant, 1997. v. 2, p. 1.649-1.679. Disponível em: <http://www.corteidh.or.cr/tablas/a12244.pdf>. Acesso em: 30 out. 2016.

VASCONCELOS, Guilherme Mantovani; GOMES, Fraikson Cleiton Fuscaldi. A desmilitarização das polícias ostensivas e a criação das polícias de ciclo completo no Brasil. Anais VI SIMPAC, Viçosa, volume 6, $\quad$ n. 1, jan. - dez. 2014, p. 7-12. Disponível em:

$<$ https://academico.univicosa.com.br/revista/index.php/RevistaSimpac/article/view/435>. Acesso em: 26 out. 2016.

WEBER, Marx. Economia e sociedade: fundamentos da sociologia compreensiva. Tradução de Regis Barbosa e Karem Elsabe Barbosa. Brasília: UNB, 2004. v. 2.

Wilson, J.Q., e Kelling, G. (1982). Broken windows: the police and neighborhood safety. Atlantic Monthly, 249(3), 29-38.

Trabalho enviado em 11 de novembro de 2018 Aceito em 25 de janeiro de 2020 